SERAFIN, Gabriela Pietsch; REUPKE, Erika Giovanini; JACOBSEN, Gilson. Inconstitucionalidade da EC 103/2019 quanto à fixação de idade mínima para a aposentadoria especial: uma abordagem à luz do direito fundamental ao meio ambiente de trabalho equilibrado. Revista Eletrônica Direito e Política, Programa de Pós-Graduação Stricto Sensu em Ciência Jurídica da UNIVALI, Itajaí, v.16, n.2, $2^{\circ}$ quadrimestre de 2021. Disponível em: www.univali.br/direitoepolitica - ISSN 1980-7791.

\title{
INCONSTITUCIONALIDADE DA EC 103/2019 QUANTO À FIXAÇÃO DE IDADE MÍNIMA PARA A APOSENTADORIA ESPECIAL: UMA ABORDAGEM À LUZ DO DIREITO FUNDAMENTAL AO MEIO AMBIENTE DE TRABALHO EQUILIBRADO
}

\author{
UNCONSTITUTIONALITY OF EC 103/2019 AS TO FIXING THE MINIMUM AGE FOR \\ SPECIAL RETIREMENT: AN APPROACH IN LIGHT OF FUNDAMENTAL LAW TO A
} BALANCED WORKING ENVIRONMENT

\author{
Gabriela Pietsch Serafin ${ }^{1}$ \\ Erika Giovanini Reupke ${ }^{2}$ \\ Gilson Jacobsen ${ }^{3}$
}

\section{RESUMO}

Este trabalho apresenta uma reflexão acerca do direito à aposentadoria especial e da fixação de idade mínima à sua fruição pela Emenda Constitucional 103/2019. A abordagem do tema explora o Estado Social, a dignidade humana e proteção social, trilhando pelo direito fundamental ao ambiente de trabalho equilibrado e à aposentadoria especial, benefício previdenciário que busca, na redução de tempo à inativação, a proteção da saúde e da vida do trabalhador-segurado sujeito a agentes nocivos em seu labor. Analisa a constitucionalidade da fixação de idade mínima à aposentadoria especial no que toca à proteção da saúde e da vida. A investigação, o tratamento dos dados e a elaboração do relato desta pesquisa são realizados com base no método indutivo.

PALAVRAS-ChAVE: Direito Social. Direito Previdenciário. Aposentadoria Especial. Emenda Constitucional 103/2019. Constitucionalidade.

1 Mestranda em Direito pelo Programa de Pós-Graduação em Direito da Universidade do Extremo Sul Catarinense - UNESC. Professora convidada no Curso de Pós-Graduação Lato Sensu em Direito Previdenciário da UNESC. Juíza Federal lotada na $3^{a}$ Vara Federal de Criciúma. E-mail: gpserafin.jfsc@gmail.com.

2 Mestranda pelo Mestrado Profissional em Direito da Universidade Federal de Santa Catarina UFSC. Professora de Direito Administrativo da Escola Superior da Magistratura Federal do Estado de Santa Catarina - ESMAFESC e da Escola Superior da Magistratura do Estado de Santa Catarina ESMESC. Juíza Federal lotada na $2^{a}$ Turma Recursal de Santa Catarina, em Florianópolis. E-mail: erika.reupke@trf4.jus.br.

\footnotetext{
3 Pós-doutor em Direito e Justiça Constitucional pela Alma Mater Studiorum Università di Bologna UNIBO/Itália; Doutor e Mestre em Ciência Jurídica pela Universidade do Vale do Itajaí UNIVALI/Brasil; Dottore di Ricerca in Diritto pubblico presso Università Degli Studi di Perugia UNIPG/Itália; Professor dos Cursos de Mestrado e Doutorado em Ciência Jurídica da UNIVALI. Juiz Federal lotado na $3^{a}$ Turma Recursal de Santa Catarina, em Florianópolis. E-mail: giljacobsen@gmail.com | ORCID: https://orcid.org/0000-0002-8250-8902.
} 
SERAFIN, Gabriela Pietsch; REUPKE, Erika Giovanini; JACOBSEN, Gilson. Inconstitucionalidade da EC 103/2019 quanto à fixação de idade mínima para a aposentadoria especial: uma abordagem à luz do direito fundamental ao meio ambiente de trabalho equilibrado. Revista Eletrônica Direito e Política, Programa de Pós-Graduação Stricto Sensu em Ciência Jurídica da UNIVALI, Itajaí, v.16, n.2, $2^{\circ}$ quadrimestre de 2021. Disponível em: www.univali.br/direitoepolitica - ISSN 1980-7791.

\section{ABSTRACT}

This paper presents a reflection on the right to special retirement and the establishment of a minimum age for its enjoyment by Constitutional Amendment 103/2019. The approach to the theme explores the Welfare State, human dignity and social protection, walking for the fundamental right to a balanced work environment and special retirement, a social security benefit that seeks to reduce the time of inactivation to protect the health and life of the worker covered with social benefits subject to harmful agents in his/her work. It analyzes the constitutionality of setting a minimum age for special retirement with regard to health and life protection. Research, data processing and reporting are conducted on the basis of the inductive method.

KEYWORDS: Social Law. Social Security Law. Special Retirement. Constitutional Amendment 103/2019. Constitutionality.

\section{INTRODUÇÃO}

O presente estudo apresenta uma reflexão acerca da aposentadoria especial e da alteração perpetrada pela Emenda Constitucional 103/2019, notadamente em relação à fixação de idade mínima para essa espécie de aposentadoria.

A abordagem inicia com a análise do Estado Social e Democrático de Direito e do direito previdenciário como direito fundamental material, cuja função é a proteção social à dignidade humana.

O trabalho também perpassa pelo direito fundamental ao ambiente de trabalho equilibrado e pela aposentadoria especial, com exame de sua natureza jurídica, evolução legislativa e proteção social à qual se destina, chegando à introdução da idade mínima como requisito à sua concessão, pela Emenda Constitucional 103/2019. E, a partir da visão constitucional originária de proteção à vida, à saúde e ao meio ambiente de trabalho equilibrado, inclusive com análise da decisão do STF no Tema $709^{4}$, propõe a inconstitucionalidade da norma derivada na estipulação da idade mínima.

A pesquisa pretende responder se, na aposentadoria especial, haverá eficácia da norma protetiva de preservação da vida, da saúde e do princípio da dignidade

4 Recurso Extraordinário 791.961, tese julgada em 08.06.2020: "709 - Possibilidade de percepção do benefício da aposentadoria especial na hipótese em que o segurado permanece no exercício de atividades laborais nocivas à saúde" (BRASIL, 2020). 
SERAFIN, Gabriela Pietsch; REUPKE, Erika Giovanini; JACOBSEN, Gilson. Inconstitucionalidade da EC 103/2019 quanto à fixação de idade mínima para a aposentadoria especial: uma abordagem à luz do direito fundamental ao meio ambiente de trabalho equilibrado. Revista Eletrônica Direito e Política, Programa de Pós-Graduação Stricto Sensu em Ciência Jurídica da UNIVALI, Itajaí, v.16, n.2, $2^{\circ}$ quadrimestre de 2021. Disponível em: www.univali.br/direitoepolitica - ISSN 1980-7791.

humana ao se fixar idade mínima à sua fruição. E tem como objetivo geral dar a compreender o contexto legislativo e doutrinário em que se insere a matéria, além de demonstrar a inconstitucionalidade da Emenda Constitucional 103/2019 ao estabelecer uma idade mínima para a aposentadoria especial.

Seu propósito é demonstrar, como principal contribuição, que a proteção subjacente a todo o ideário de uma aposentadoria especial, ao delimitar o tempo de exposição a agentes nocivos, nunca foi fortuita ou fruto do acaso, mas, sim, que partiu da análise das condições epidemiológicas de exposição a agentes agressivos à saúde, buscando a garantia da saúde e da vida do trabalhador.

Assim, não haveria razão científica para que análises econômicas, financeiras ou demográficas justificassem a manutenção do trabalhador em atividade nociva à sua saúde até o cômputo de idade em tempo superior ao exigido à aposentação.

A justificativa para a presente imersão está fundamentada na necessidade de um estudo acadêmico sobre essa alteração substancial na aposentadoria especial; e sua relevância científica está em poder contribuir, de algum modo, para se demonstrar que a natureza jurídica da aposentadoria especial não se mostra condizente com a exigência de idade mínima.

Para tanto, utilizam-se os seguintes referenciais teóricos: Garcia-Pelayo, quanto ao Estado Social e Democrático de Direito; Herrera Flores, sobre dignidade humana e proteção social; Castro, Lazzari e Martins, para aposentadoria especial; Silva, Padilha e Melo, no que diz respeito ao direito ao meio ambiente equilibrado do trabalho; e, por fim, acerca de controle de constitucionalidade de emendas constitucionais, a luz interpretativa do Supremo Tribunal Federal.

Para além desta Introdução, o artigo está estruturado nas seguintes subseções: 2 Estado Social e Democrático de Direito; 3 Dignidade humana e proteção social; 4 Do direito fundamental ao meio ambiente de trabalho equilibrado; 5 Do direito à aposentadoria especial; 6 Do julgamento do Tema 709 do Supremo Tribunal Federal: constitucionalidade do art. 57, $\S 8^{\circ}$, da Lei no 8.213/91 impossibilidade de percepção do benefício de aposentadoria especial independentemente do afastamento do beneficiário das atividades laborais 
SERAFIN, Gabriela Pietsch; REUPKE, Erika Giovanini; JACOBSEN, Gilson. Inconstitucionalidade da EC 103/2019 quanto à fixação de idade mínima para a aposentadoria especial: uma abordagem à luz do direito fundamental ao meio ambiente de trabalho equilibrado. Revista Eletrônica Direito e Política, Programa de Pós-Graduação Stricto Sensu em Ciência Jurídica da UNIVALI, Itajaí, v.16, n.2, $2^{\circ}$ quadrimestre de 2021. Disponível em: www.univali.br/direitoepolitica - ISSN 1980-7791.

nocivas a sua saúde; 7 Aposentadoria especial: desconstituição inconstitucional de um direito; 8 Considerações finais; 9 Referências.

O método utilizado na fase de investigação foi o indutivo, que também é a base de abordagem para o desenvolvimento do presente trabalho. $\mathrm{Na}$ fase de tratamento de dados, recorreu-se ao método analítico em combinação com o método histórico, sendo que a técnica da pesquisa bibliográfica, por meio de livros, artigos científicos e legislação pertinente, forneceu o suporte investigatório.

\section{ESTADO SOCIAL E DEMOCRÁTICO DE DIREITO}

Pela lógica liberal, ao Estado incumbia apenas a defesa do indivíduo contra a autoridade, o que favorecia as aspirações da classe economicamente dominante naquela época. Paulo Bonavides ${ }^{5}$, ao referir-se à base ideológica daquele sistema, classifica-o como o da tutela do indivíduo e da propriedade privada, "premissa essencial do sistema capitalista".

Por outro lado, com o avançar do tempo, a vontade geral passa a ser a base instrumental política do Estado Social, pois permite "acesso a um socialismo moderado, por via democrática"6

Realmente, segundo Paulo Márcio $\mathrm{Cruz}^{7}$, com o tempo, a igualdade meramente formal já não era suficiente para a nova sociedade surgida da industrialização burguesa, e, a partir das três primeiras décadas do século $X X$, o Estado Contemporâneo [Liberalismo Contemporâneo] sucedeu o Estado Liberal original. Assim, com a Revolução Russa, a crise do capitalismo de 1929 e as duas grandes guerras, o liberalismo ganhou novos contornos e tornou-se mais permissivo.

Chama-se Liberalismo Contemporâneo aquele surgido após a Primeira Guerra Mundial, ainda com amplas esferas de liberdade, mas já admitindo a intervenção

${ }^{5}$ BONAVIDES, Paulo. Do Estado Liberal ao Estado Social: 7a ed. São Paulo: Malheiros, 2004, p. 168.

6 BONAVIDES, Paulo. Do Estado Liberal ao Estado Social: 7a ed. São Paulo: Malheiros, 2004, p. 170-175.

7 CRUZ, Paulo Márcio. Política, poder, ideologia e Estado contemporâneo. 3. ed. 1. tir. Curitiba: Juruá, 2003, p. 109. 
SERAFIN, Gabriela Pietsch; REUPKE, Erika Giovanini; JACOBSEN, Gilson. Inconstitucionalidade da EC 103/2019 quanto à fixação de idade mínima para a aposentadoria especial: uma abordagem à luz do direito fundamental ao meio ambiente de trabalho equilibrado. Revista Eletrônica Direito e Política, Programa de Pós-Graduação Stricto Sensu em Ciência Jurídica da UNIVALI, Itajaí, v.16, n.2, 20 quadrimestre de 2021. Disponível em: www.univali.br/direitoepolitica - ISSN 1980-7791.

do Estado em alguns âmbitos sociais ${ }^{8}$

Esse avanço, porém, não foi uniforme nem foi perceptível em todos os Estados. Isso porque, lembra $\mathrm{Cruz}^{9}$ : "alguns países enfrentaram a crise do Estado liberal substituindo-o por ditaduras, militares ou civis, ou por Estados totalitários". Outros, no entanto, "entraram numa decisiva via de ampliação da representação política, reformismo social - assumindo os direitos sociais - e intervencionismo redistributivo".

Entre o fim da Segunda Guerra Mundial e o início dos anos setenta passa a haver um consenso, nos países ocidentais com regimes democráticos, entre todas as forças políticas majoritárias na aplicação das assim chamadas políticas de Estado de Bem-Estar ${ }^{10}$. Dito Estado de Bem-Estar, ainda com raiz filosófica no utilitarismo, propugnava a maior felicidade para o maior número de pessoas, mas não resistiria, no final dos anos setenta, ao esgotamento do modelo keynesiano. E o que se observou, então, foi o retorno de teses liberais que se supunham superadas ${ }^{11}$

Em nota de rodapé, Cruz ${ }^{12}$, tece oportuno esclarecimento: "Estado de Bem-Estar é sinônimo de Estado Social-Democrata ou simplesmente Estado Social, que são denominações diferentes para um mesmo modelo ideológico de Estado, cada um deles com algumas características próprias, $[\ldots]^{\prime \prime}$.

O Estado passou a chamar para si - sobretudo por meio da intervenção direta nos domínios econômico, social e cultural - a solução dos problemas mais emergentes da sociedade. Fez-se sentir a sensação generalizada de que a

\footnotetext{
8 CRUZ, Paulo Márcio. Política, poder, ideologia e Estado contemporâneo. 3. ed. 1. tir. Curitiba: Juruá, 2003, p. 120.

9 CRUZ, Paulo Márcio. Política, poder, ideologia e Estado contemporâneo. 3. ed. 1. tir. Curitiba: Juruá, 2003, p. 12.

10 "Estado de Bem-Estar é o produto da reforma do modelo clássico de Estado Liberal que pretendeu superar as crises de legitimidade que este possa sofrer, sem abandonar sua estrutura jurídico-política. Caracteriza-se pela união da tradicional garantia das liberdades individuais com o reconhecimento, como direitos coletivos, de certos serviços sociais que o Estado providencia, pela intervenção, aos cidadãos, de modo a proporcionar iguais oportunidades a todos." (CRUZ, 2003, p. 163).

${ }^{11}$ CRUZ, Paulo Márcio. Política, poder, ideologia e Estado contemporâneo. 3. ed. 1. tir. Curitiba: Juruá, 2003, p. 123.

${ }^{12}$ CRUZ, Paulo Márcio. Política, poder, ideologia e Estado contemporâneo. 3. ed. 1. tir. Curitiba: Juruá, 2003, p. 163-164.
} 
SERAFIN, Gabriela Pietsch; REUPKE, Erika Giovanini; JACOBSEN, Gilson. Inconstitucionalidade da EC 103/2019 quanto à fixação de idade mínima para a aposentadoria especial: uma abordagem à luz do direito fundamental ao meio ambiente de trabalho equilibrado. Revista Eletrônica Direito e Política, Programa de Pós-Graduação Stricto Sensu em Ciência Jurídica da UNIVALI, Itajaí, v.16, n.2, $2^{\circ}$ quadrimestre de 2021. Disponível em: www.univali.br/direitoepolitica - ISSN 1980-7791.

intervenção do Estado era algo indispensável, ao menos para se alcançar o crescimento econômico sob regras capitalistas e para se garantir a paz ${ }^{13}$

E as Constituições mexicana [1917] e alemã de Weimar ${ }^{14}$ [1919] foram as primeiras a prever, expressamente, a intervenção estatal nos domínios social e econômico. No Brasil, a Constituição de 1934, logo revogada pela Constituição de 1937, também previu, amplamente, a intervenção do Estado. Época em que se forjou a expressão Estado Social, por inspiração de Hermann Heller ${ }^{15}$

Norberto Bobbio ${ }^{16}$, formula oportuna síntese acerca da transformação do Estado, cotejando-a com a evolução dos direitos e dos próprios indivíduos:

No Estado despótico, os indivíduos singulares só têm deveres e não direitos. No Estado absoluto, os indivíduos possuem, em relação ao soberano, direitos privados. No Estado de direito, o indivíduo tem, em face do Estado, não só direitos privados, mas também direitos públicos. O Estado de direito é o Estado dos cidadãos.

Novais ${ }^{17}$, afirma que ao Estado Social não implica apenas 0 mero intervencionismo, mas também uma nova configuração e interação nas relações entre Estado e sociedade. Trata-se, desse modo, de vinculação ao princípio democrático, em que o cidadão não é apenas receptor de políticas públicas, mas participante ativo de sua elaboração. A esse respeito, como refere GarciaPelayo $^{18}$, o que caracteriza o Estado Social não é a função assistencial nem a política de bem-estar, mas sim a sua própria configuração global. Trata-se de uma democracia social que reivindica a socialização do Estado, a fim de que os cidadãos participem da formação de sua vontade política, bem como da

${ }_{13}$ CRUZ, Paulo Márcio. Política, poder, ideologia e Estado contemporâneo. 3. ed. 1. tir. Curitiba: Juruá, 2003, p. 164 e p. 186.

${ }^{14}$ Cidade da Saxônia na qual a Constituição Alemã de 1919 foi aprovada.

15 CRUZ, Paulo Márcio. Política, poder, ideologia e Estado contemporâneo. 3. ed. 1. tir. Curitiba: Juruá, 2003, p. 210-211.

${ }^{16}$ BOBBIO, Norberto. A era dos direitos. Tradução de: Carlos Nelson Coutinho. Rio de Janeiro: Campus, 1992, p. 61.

17 NOVAIS, Jorge Reis. Contributo para uma teoria do Estado de direito: do Estado de direito liberal ao Estado social e democrático de direito. Coimbra: Almedina, 2006, p. 183.

${ }^{18}$ GARCIA-PELAYO, Manuel. As transformações do Estado contemporâneo. Tradução de Agassiz Almeida Filho. Rio de Janeiro: Forense, 2009, p. 35. 
SERAFIN, Gabriela Pietsch; REUPKE, Erika Giovanini; JACOBSEN, Gilson. Inconstitucionalidade da EC 103/2019 quanto à fixação de idade mínima para a aposentadoria especial: uma abordagem à luz do direito fundamental ao meio ambiente de trabalho equilibrado. Revista Eletrônica Direito e Política, Programa de Pós-Graduação Stricto Sensu em Ciência Jurídica da UNIVALI, Itajaí, v.16, n.2, $2^{\circ}$ quadrimestre de 2021. Disponível em: www.univali.br/direitoepolitica - ISSN 1980-7791.

distribuição e atribuição de bens e serviços. Garcia-Pelayo ${ }^{19}$, caracteriza o Estado Social nos seguintes termos:

[...], por Estado Social devemos entender não apenas uma configuração histórica concreta, mas também um conceito claro e distinto frente a outras estruturas estatais. Por isso, precisamos considerá-lo como um sistema democraticamente organizado, ou seja, como um sistema onde a sociedade não só participa passivamente como receptora de bens e serviços. Trata-se de um sistema em que, através de suas organizações, a sociedade é parte ativa na formulação da vontade geral do Estado, bem como na construção das políticas distributivas e de outras prestações estatais. Dito de outro modo, qualquer que seja o conteúdo social, sua atualização precisa vincular-se a um processo democrático, mais complexo, certamente, do que a simples democracia política, uma vez que ele deve estender-se a outras dimensões.

Com base nessas premissas, ou seja, no entendimento do Estado Social como um sistema democraticamente organizado, exsurge a ideia de Estado Democrático de Direito, o qual possui estrutura similar à do modelo clássico liberal, com suas garantias jurídico-legais, e também é dotado da preocupação social intrínseca ao Estado Social. Para Novais ${ }^{20}$, o Estado Social e Democrático de Direito é:

[...] conceito que exprime a limitação e vinculação jurídica do Estado com vista à garantia dos direitos fundamentais do homem e à promoção das condições do livre e autónomo desenvolvimento da personalidade individual - acolher e integrar juridicamente as transformações económicas e sociais democraticamente decididas e, com tal alcance, constituir-se em princípio estruturante da ordem constitucional das sociedades democráticas contemporâneas.

Essa nova forma de Estado vai além, pois visa a incorporar, concretamente, o princípio democrático como seu elemento constitutivo, de forma a garantir a

19 GARCIA-PELAYO, Manuel. As transformações do Estado contemporâneo. Tradução de Agassiz Almeida Filho. Rio de Janeiro: Forense, 2009, p. 35.

20 NOVAIS, Jorge Reis. Contributo para uma teoria do Estado de direito: do Estado de direito liberal ao Estado social e democrático de direito. Coimbra: Almedina, 2006, p. 218. 
SERAFIN, Gabriela Pietsch; REUPKE, Erika Giovanini; JACOBSEN, Gilson. Inconstitucionalidade da EC 103/2019 quanto à fixação de idade mínima para a aposentadoria especial: uma abordagem à luz do direito fundamental ao meio ambiente de trabalho equilibrado. Revista Eletrônica Direito e Política, Programa de Pós-Graduação Stricto Sensu em Ciência Jurídica da UNIVALI, Itajaí, v.16, n.2, $2^{\circ}$ quadrimestre de 2021. Disponível em: www.univali.br/direitoepolitica - ISSN 1980-7791.

justiça social e a efetiva participação do povo no controle das decisões estatais. Conforme Silva ${ }^{21}$ :

Conclui-se daí que a igualdade do Estado de Direito, na concepção clássica, se funda num elemento puramente formal e abstrato, qual seja, a generalidade das leis. Não tem base material que se realize na vida concreta. A tentativa de corrigir isso, como vimos, foi a construção do Estado Social de Direito, que, no entanto, não foi capaz de assegurar a justiça social nem a autêntica participação democrática do povo no processo político.

A concretização do pensamento democrático encontra diversos obstáculos, razão pela qual se pode dizer que o Estado Social e Democrático de Direito representa um intento de vir a ser, evitando-se, sempre, qualquer retrocesso.

Nesse sentido, Sarlet ${ }^{22}$ defende a vedação de retrocesso social como princípio constitucional fundamental implícito, aplicável a todos os direitos fundamentais, mas, especialmente, aos direitos sociais prestacionais, extraído tanto do princípio do Estado de Direito (no âmbito da proteção da confiança e da estabilidade das relações jurídicas inerentes à segurança jurídica), quanto do princípio do Estado Social, na condição de garantia da manutenção dos graus mínimos de segurança social alcançados, sendo, de resto, corolário da máxima eficácia e efetividade das normas de direitos fundamentais sociais e do direito à segurança jurídica, assim como da própria dignidade da pessoa humana.

Lembra, ainda, que, conforme observações feitas por Abramovich e Courtis ${ }^{23}$ o sistema de proteção internacional impõe a progressiva implementação da proteção social por parte dos Estados, estando implicitamente vedado, por isso, o retrocesso em relação aos direitos sociais já concretizados ${ }^{24}$

\footnotetext{
${ }^{21}$ SILVA, José Afonso da. Curso de direito constitucional positivo. 24. ed. São Paulo: Revista dos Tribunais, 2005, p. 118.

22 SARLET, Ingo Wolfgang. A eficácia dos direitos fundamentais. 10. ed. Porto Alegre: Livraria do Advogado, 2011, p. 450-451.

23 ABRAMOVICH, Victor; COURTIS, Christian. Los derechos sociales como derechos exigibles. Madrid: Trotta, 2002, p. 92.

${ }^{24}$ SARLET, Ingo Wolfgang. A eficácia dos direitos fundamentais. 10. ed. Porto Alegre: Livraria do Advogado, 2011, p. 448.
} 
SERAFIN, Gabriela Pietsch; REUPKE, Erika Giovanini; JACOBSEN, Gilson. Inconstitucionalidade da EC 103/2019 quanto à fixação de idade mínima para a aposentadoria especial: uma abordagem à luz do direito fundamental ao meio ambiente de trabalho equilibrado. Revista Eletrônica Direito e Política, Programa de Pós-Graduação Stricto Sensu em Ciência Jurídica da UNIVALI, Itajaí, v.16, n.2, $2^{\circ}$ quadrimestre de 2021. Disponível em: www.univali.br/direitoepolitica - ISSN 1980-7791.

\section{DIGNIDADE HUMANA E PROTEÇÃO SOCIAL}

A dignidade humana é reconhecida como um valor supremo, o primeiro dos valores fundamentais em torno do qual gravitam todas as demais normas, em especial as normas que definem direitos fundamentais e direitos humanos.

Devem sempre (os direitos fundamentais e humanos) ser contextualizados dentro das relações sociais, abandonando a perspectiva abstrata e formalista que tradicionalmente Ihes é atribuída, permitindo sua materialização como forma de combate à desigualdade e à injustiça social.

Nas palavras de Herrera Flores ${ }^{25}$ :

Os direitos humanos não são categorias prévias à ação política ou às práticas econômicas. A luta pela dignidade humana é a razão e a consequência da luta pela democracia e pela justiça. Não estamos diante de privilégios, meras declarações de boas intenções ou postulados metafísicos que exponham uma definição da natureza humana isolada das situações vitais. Pelo contrário, os direitos humanos constituem a afirmação da luta do ser humano para ver cumpridos seus desejos e necessidades nos contextos vitais em que está situado.

Por isso mesmo, todo o conjunto de direitos e garantias que resguardam os seres humanos, "detém como finalidade básica o respeito a sua dignidade, esta adquirida mediante a proteção contra o poder do Estado e a instituição de condições mínimas para a vivência e o desenvolvimento da personalidade humana, bem como o seu pleno crescimento e bem-estar" ${ }^{\prime 26}$

O constituinte de 1988 procurou assegurar a maior eficácia possível aos direitos fundamentais, concedendo primazia à garantia da dignidade da pessoa humana e aos valores sociais. No preâmbulo da nova ordem constitucional consta a

\footnotetext{
25 HERRERA FLORES, Joaquin. A (re)invenção dos direitos humanos. Florianópolis: Fundação Boiteux, 2009, p. 19.

${ }^{26}$ DANTAS, Marcelo Buzaglo; BONISSONI, Natammy Luana de Aguiar; FERRER, Gabriel Real. O Processo de Internacionalização da Proteção Ambiental e dos Direitos Humanos. In: GARCIA, Denise Schmitt Siqueira; DANTAS, Marcelo Buzaglo; GIMENEZ, Andrés Molina (Org.). Sociedade, Governança e Meio Ambiente [recurso eletrônico]. 1 ed. Itajaí: UNIVALI, 2017 (Coleção Estado, transnacionalidade e sustentabilidade; t. 3), p. 197. Disponível em: https://www.univali.br/vida-no-campus/editora-univali/e-books/Documents/ecjs/E book\%202017\%20SOCIEDADE,\%20GOVERNAN\%C3\%87A\%20E\%20MEIO\%20AMBIENTE\%20\%E2 \%80\%93\%20TOMO\%2003.pdf. Acesso em: 22 mar. 2021.
} 
SERAFIN, Gabriela Pietsch; REUPKE, Erika Giovanini; JACOBSEN, Gilson. Inconstitucionalidade da EC 103/2019 quanto à fixação de idade mínima para a aposentadoria especial: uma abordagem à luz do direito fundamental ao meio ambiente de trabalho equilibrado. Revista Eletrônica Direito e Política, Programa de Pós-Graduação Stricto Sensu em Ciência Jurídica da UNIVALI, Itajaí, v.16, n.2, $2^{\circ}$ quadrimestre de 2021. Disponível em: www.univali.br/direitoepolitica - ISSN 1980-7791.

finalidade de se assegurar o exercício dos direitos sociais e individuais, a liberdade, a segurança, o bem-estar, o desenvolvimento, a igualdade e a justiça como valores supremos de uma sociedade fraterna, pluralista e sem preconceitos, fundada na harmonia social e comprometida, na ordem interna e internacional, com a solução pacífica das controvérsias.

O sistema de Seguridade Social eleito foi construído sobre os pilares trazidos pelos novos valores e fundamentos elencados no preâmbulo e nos artigos $1^{\circ} \mathrm{e}$ 30 da Constituição, e foi inserido em um capítulo à parte, distinto dos direitos dos trabalhadores, dentro da Ordem Social, que tem como base o primado do trabalho e como objetivo o bem-estar e a justiça social.

O direito à Previdência Social vem expressamente consagrado no artigo $6^{\circ}$ da Constituição Federal como direito social, erigido à proteção diferenciada do artigo $5^{\circ}, \S 1^{\circ}$, e do artigo 60, $\S 4^{\circ}$, inciso IV, ambos da Carta de 1988, já que os direitos sociais integram o Título II da Constituição, que prevê os direitos e garantias fundamentais. Além disso, pela sua especial ligação aos valores da vida, da liberdade, da igualdade e da dignidade humana, para além de ser promotor de uma sociedade livre, justa e solidária, responsável, também, parcialmente, pela erradicação da pobreza e da marginalização e pela redução das desigualdades sociais, é possível atribuir-lhe, da mesma forma, fundamentalidade material ${ }^{27}$

Ainda que nem todos os direitos fundamentais possuam um conteúdo diretamente fundado no princípio da dignidade da pessoa humana ${ }^{28}$, no que tange ao direito à Previdência Social, ao menos em relação a grande parte de suas prestações, é possível relacioná-lo a tal princípio, já que, indubitavelmente, referido direito se conecta ao direito, à vida e à preservação da integridade física e moral, servindo de alavanca à promoção da liberdade e da igualdade material. Afinal, o amparo previdenciário garantido pela sociedade por intermédio do Estado não tem outra finalidade senão a de prover a subsistência dos indivíduos

\footnotetext{
27 HERRERA FLORES, Joaquin. A (re)invenção dos direitos humanos. Florianópolis: Fundação Boiteux, 2009, p. 77-78.

${ }^{28}$ HERRERA FLORES, Joaquin. A (re)invenção dos direitos humanos. Florianópolis: Fundação Boiteux, 2009, p. 119-126.
} 
SERAFIN, Gabriela Pietsch; REUPKE, Erika Giovanini; JACOBSEN, Gilson. Inconstitucionalidade da EC 103/2019 quanto à fixação de idade mínima para a aposentadoria especial: uma abordagem à luz do direito fundamental ao meio ambiente de trabalho equilibrado. Revista Eletrônica Direito e Política, Programa de Pós-Graduação Stricto Sensu em Ciência Jurídica da UNIVALI, Itajaí, v.16, n.2, $2^{\circ}$ quadrimestre de 2021. Disponível em: www.univali.br/direitoepolitica - ISSN 1980-7791.

- e dos que dele dependem -, que, por motivos diversos, têm sua capacidade laborativa subtraída ou mesmo negado o acesso ao trabalho.

Nesse sentido, Rocha ${ }^{29}$, ao citar lição de Benda, para quem a obrigação do Estado de respeitar a dignidade do indivíduo não se restringe à expectativa de não ser tratado arbitrariamente, abrangendo uma obrigação prestatória quando o indivíduo não pode, de outra maneira, prover uma existência humanamente digna, justifica a fundamentalidade material do direito à Previdência Social, na medida em que:

[...] é justamente nos momentos nos quais os cidadãos, inseridos na sociedade por força de sua capacidade de trabalho (substancial maioria da população), têm a sua força laboral afetada, ou mesmo negado o acesso ao trabalho, como é cada vez mais comum por força do modelo econômico excludente, que a previdência evidencia seu papel nuclear para a manutenção do ser humano dentro de um nível existencial minimamente adequado.

Ligado aos direitos sociais, que têm por finalidade básica promover a liberdade do indivíduo através do Estado, o direito a uma Previdência Social implica, basicamente, na possibilidade de dispor do necessário para enfrentar as contingências que podem ocorrer na vida dos indivíduos. A finalidade da Previdência Social organizada pelo ente estatal é garantir a subsistência daqueles que sofrem as consequências de determinados riscos sociais estabelecidos pela legislação e que afetam a sua capacidade de subsistência.

A Seguridade Social e, por consequência, a Previdência Social podem ser definidas como direitos fundamentais: tem por finalidade a proteção daqueles que, por motivos diversos, necessitam da presença do Estado à subsistência, o que está intimamente vinculado à dignidade da pessoa humana.

A aposentadoria especial é um dos benefícios previdenciários que se destina a compensar o maior desgaste do segurado que trabalha em exposição a agentes

${ }^{29}$ ROCHA, Daniel Machado da. O direito fundamental à previdência social. Porto Alegre: Livraria do Advogado, 2004, p. 111. 
SERAFIN, Gabriela Pietsch; REUPKE, Erika Giovanini; JACOBSEN, Gilson. Inconstitucionalidade da EC 103/2019 quanto à fixação de idade mínima para a aposentadoria especial: uma abordagem à luz do direito fundamental ao meio ambiente de trabalho equilibrado. Revista Eletrônica Direito e Política, Programa de Pós-Graduação Stricto Sensu em Ciência Jurídica da UNIVALI, Itajaí, v.16, n.2, $2^{\circ}$ quadrimestre de 2021. Disponível em: www.univali.br/direitoepolitica - ISSN 1980-7791.

prejudiciais à saúde ou à integridade física ${ }^{30} \mathrm{com}$ a respectiva redução do tempo de serviço exigido, que pode ser de 15, 20 ou 25 anos, objetivando permitir que o segurado possa deixar de exercer a atividade prejudicial, resguardando sua saúde e sua vida.

\section{DO DiReito fundamental AO MEIO AMBiente DE tRABAlHO EQUILIBRADO}

A Constituição Federal de 1988 consagrou como obrigação do Poder Público a defesa, a preservação e a garantia de efetividade do direito fundamental ao meio ambiente ecologicamente equilibrado, bem de uso comum do povo e essencial à sadia qualidade de vida. A menção constitucional ao meio ambiente do trabalho surge de forma oblíqua quando elenca como atribuição do Sistema Único de Saúde - SUS colaborar na proteção do meio ambiente, nele compreendido o do trabalho - art. 200, VIII, da CF, BRASIL, 1988.

De fato, ainda que o meio ambiente não figure no título consagrado aos direitos e às garantias fundamentais, a doutrina considera que os direitos ligados ao meio ambiente constituem no plano material, e também no formal, direitos fundamentais.

De acordo com Canotilho ${ }^{31}$

A dimensão objetiva das normas-tarefa e normas-fim
relativas ao meio ambiente apontam para a
constitucionalização de bens (ou valores) jurídicos
constitucionais relevantes na interpretação-concretização de
outras regras e princípios, bem assim nos juízos de
ponderação na solução de conflitos. As normas-fim e
normas-tarefa ambientalmente relevantes são normas
constitucionais impositivas. Mas, não apenas isso, também
possuem um caráter dinâmico, no qual implica uma
atualização e um aperfeiçoamento dos instrumentos

30 Redação original do art. 202, II, da CF/88 (atual redação pela EC 103/2019 - art. 201, §10, II, a qual suprimiu agentes prejudiciais à integridade física) (BRASIL, 1988).

31 CANOTILHO, Joaquim José Gomes. Estudos sobre direitos fundamentais: o direito ao ambiente como direito subjetivo. Rio de Janeiro: Revista dos Tribunais, 2008, p. 48. 
SERAFIN, Gabriela Pietsch; REUPKE, Erika Giovanini; JACOBSEN, Gilson. Inconstitucionalidade da EC 103/2019 quanto à fixação de idade mínima para a aposentadoria especial: uma abordagem à luz do direito fundamental ao meio ambiente de trabalho equilibrado. Revista Eletrônica Direito e Política, Programa de Pós-Graduação Stricto Sensu em Ciência Jurídica da UNIVALI, Itajaí, v.16, n.2, $2^{\circ}$ quadrimestre de 2021. Disponível em: www.univali.br/direitoepolitica - ISSN 1980-7791.

destinados à proteção do ambiente perante os novos perigos de agressões ecológicas.

É possível concluir, da interpretação do artigo 225 da Constituição Federal, que a proteção ambiental, além de ser um direito, é também um dever fundamental, que se caracteriza pela obrigação, incumbida ao Estado e a cada um dos indivíduos, de manter um ambiente saudável, sadio e equilibrado.

Nesse contexto, importante é a reflexão de Norma Sueli Padilha ${ }^{32}$ :

Quando a Constituição Federal, em seu art. 225, fala em meio ambiente ecologicamente equilibrado, está mencionando todos os aspectos do meio ambiente. $\mathrm{E}$, ao dispor, ainda, que o homem para encontrar uma sadia qualidade de vida necessita viver neste ambiente ecologicamente equilibrado, tornou obrigatória também a proteção do ambiente no qual o homem, normalmente, passa a maior parte de sua vida produtiva, qual seja, o do trabalho.

José Afonso da Silva ${ }^{33}$, ao tratar do tema meio ambiente do trabalho, ensina:

Merece referência em separado o meio ambiente do trabalho, como o local em que se desenrola boa parte da vida do trabalhador, cuja qualidade de vida está, por isso, em íntima dependência da qualidade daquele ambiente. É um meio ambiente que se insere no artificial, mas digno de tratamento especial, tanto que a Constituição o menciona explicitamente no art. 200, VIII, ao estabelecer que uma das atribuições do Sistema Único de Saúde consiste em colaborar na proteção do ambiente, nele compreendido o trabalho.

Com o mesmo aprumo, Raimundo Simão de $\mathrm{Melo}^{34}$ pondera:

O meio ambiente do trabalho adequado e seguro é um dos mais importantes e fundamentais direitos do cidadão trabalhador, o qual, se desrespeitado, provoca agressão a toda a sociedade, que, no final das contas é quem custeia a previdência social, que, por inúmeras razões, corre o risco

32 PADILHA, Norma Sueli. Do meio ambiente do trabalho equilibrado. São Paulo: LTr, 2002, p. 32.

${ }_{33}$ SILVA, José Afonso da. Direito ambiental constitucional. 5. ed. São Paulo: Malheiros, 2004, p. 21.

${ }^{34}$ MELO, Raimundo Simão de. Direito ambiental do trabalho e a saúde do trabalhador. 5. ed. São Paulo: LTr, 2013, p. 29. 
SERAFIN, Gabriela Pietsch; REUPKE, Erika Giovanini; JACOBSEN, Gilson. Inconstitucionalidade da EC 103/2019 quanto à fixação de idade mínima para a aposentadoria especial: uma abordagem à luz do direito fundamental ao meio ambiente de trabalho equilibrado. Revista Eletrônica Direito e Política, Programa de Pós-Graduação Stricto Sensu em Ciência Jurídica da UNIVALI, Itajaí, v.16, n.2, $2^{\circ}$ quadrimestre de 2021. Disponível em: www.univali.br/direitoepolitica - ISSN 1980-7791.

de não poder mais oferecer proteção até mesmo aos seus segurados no próximo século.

Importa mencionar, ademais, que tanto o princípio da precaução quanto o da prevenção, tão caros para a própria formação do direito ambiental, encontram fértil campo de aplicação no âmbito do meio ambiente de trabalho.

O princípio da prevenção exsurge expressamente nos incisos II, III, IV e V do parágrafo $1^{0}$ do artigo 225 da CF/88 ${ }^{35}$. Consiste na adoção antecipada de medidas definidas que possam evitar a ocorrência de um dano provável, numa determinada situação, reduzindo ou eliminando suas causas, quando se tem conhecimento de um risco concreto.

Já o princípio da precaução consiste na adoção antecipada de medidas amplas que possam evitar a ocorrência de possível ameaça à saúde e segurança. Aponta para a necessidade de comportamento cuidadoso, marcado pelo bom senso, de abrangência ampla, direcionado para a redução ou eliminação das situações adversas à saúde e segurança.

Assim, enquanto o princípio da prevenção tem o escopo de evitar determinados riscos certos, o princípio da precaução aponta para a adoção de condutas acautelatórias gerais, considerando o risco abstrato e potencial, dando o benefício da dúvida em favor o meio ambiente devido à falta de certeza ${ }^{36}$

Marcelo Abelha Rodrigues ${ }^{37}$ esclarece que, enquanto "a prevenção relaciona-se com a adoção de medidas que corrijam ou evitem danos previsíveis, a precaução também age prevenindo, mas antes disso, evita-se o próprio risco ainda imprevisto."

35 BRASIL. [Constituição Federal (1988)]. Constituição da República Federativa do Brasil de 1988. Brasília, DF, 5 de outubro de 1988. Disponível em: http://www.planalto.gov.br/ccivil_03/constituicao/ConstituicaoCompilado.htm. Acesso em: 26 fev. 2021.

${ }^{36}$ TIGRE, Maria Antonia. Implementing Constitutional Environmental Rights in the Amazon Rainforest. In: DALY, Erin; MAY, James R. (Edit.). Implementing Environmental Constitutionalism: current global challenges. 1. ed. New York: Cambridge University Press, 2018, p. 73.

37 RODRIGUES, Marcelo Abelha. Elementos de direito ambiental: parte geral. São Paulo: Revista dos Tribunais, 2005, p. 207. 
SERAFIN, Gabriela Pietsch; REUPKE, Erika Giovanini; JACOBSEN, Gilson. Inconstitucionalidade da EC 103/2019 quanto à fixação de idade mínima para a aposentadoria especial: uma abordagem à luz do direito fundamental ao meio ambiente de trabalho equilibrado. Revista Eletrônica Direito e Política, Programa de Pós-Graduação Stricto Sensu em Ciência Jurídica da UNIVALI, Itajaí, v.16, n.2, $2^{\circ}$ quadrimestre de 2021. Disponível em: www.univali.br/direitoepolitica - ISSN 1980-7791.

Cristiane Derani ${ }^{38}$ ressalta que a aplicação do princípio da precaução objetiva "garantir uma suficiente margem de segurança da linha de perigo" e, por isso, antecede a sua manifestação. É um comportamento de cautela, que visa a precaver para evitar um possível risco, ainda que indefinido, procurando reduzir o "potencial danoso oriundo do conjunto de atividade." Precaução é atitude de cuidado, in dubio pro securitate, que assim surgiu como linha mestra do direito ambiental, cuja aplicação passa a ter importância cada vez maior, inclusive em se tratando de meio ambiente do trabalho, notadamente após a promulgação do Código Civil de 2002, que no parágrafo único do artigo 927 agasalhou a teoria do risco na fixação da responsabilidade objetiva.

Na seara trabalhista há um arcabouço infraconstitucional para sustentação do modelo de prevenção e de precaução. Com efeito, o inciso I do artigo 157 da CLT imputa às empresas a obrigação de "cumprir e fazer cumprir" as regras de segurança, enquanto o item II, do mesmo artigo, a de "instruir os empregados, através de ordens de serviço, quanto às precauções a tomar no sentido de evitar acidentes do trabalho ou doenças ocupacionais"; já o seu artigo 158 atribui aos empregados o encargo de "observar as normas de segurança e medicina do trabalho, inclusive as instruções" acima referidas ${ }^{39}$

A instituição da Comissão Interna de Prevenção de Acidentes de Trabalho (CIPA) (NR 5), o Serviço Especializado em Engenharia de Segurança e em Medicina do Trabalho (SESMT) (NR 4), o Programa de Prevenção de riscos ambientais (PPRA) (NR 9) e o Programa de Controle Médico e Saúde Ocupacional (PCMSO) (NR 7) foram iniciativas pioneiras que demonstraram a importância da conduta de prevenção e precaução para evitar lesão à saúde do trabalhador, abrindo uma nova senda quanto à edificação do padrão normativo destinado a disciplinar o meio ambiente de trabalho.

O Decreto 7.602, de 7 de novembro de 2011, que dispõe sobre Política Nacional de Segurança e Saúde no Trabalho - PNSST, prioriza as ações de promoção,

\footnotetext{
38 DERANI, Cristiane. Direito ambiental econômico. São Paulo: Saraiva, 2008, p. 149-152.

39 BRASIL. Decreto-Lei no 5.452, de $1^{\circ}$ de maio de 1943. Aprova a Consolidação das Leis do Trabalho. Rio de Janeiro, 01 mai. 1943. Disponível em: http://www.planalto.gov.br/ccivil_03/Decreto-Lei/Del5452.htm. Acesso em: 26 fev. 2021.
} 
SERAFIN, Gabriela Pietsch; REUPKE, Erika Giovanini; JACOBSEN, Gilson. Inconstitucionalidade da EC 103/2019 quanto à fixação de idade mínima para a aposentadoria especial: uma abordagem à luz do direito fundamental ao meio ambiente de trabalho equilibrado. Revista Eletrônica Direito e Política, Programa de Pós-Graduação Stricto Sensu em Ciência Jurídica da UNIVALI, Itajaí, v.16, n.2, $2^{\circ}$ quadrimestre de 2021. Disponível em: www.univali.br/direitoepolitica - ISSN 1980-7791.

proteção e prevenção sobre as de assistência, reabilitação e reparação, apontando para a necessidade de eliminação ou redução dos riscos nos ambientes de trabalho.

No âmbito internacional, a Organização Internacional do Trabalho (OIT) prestigia o princípio da prevenção em várias Convenções. A Convenção no 148, por exemplo, que trata da contaminação do ar, ruído e vibrações, em seu art. 40, item 1, determina que a legislação nacional deva dispor sobre a adoção de medidas no local de trabalho para prevenir e limitar os riscos profissionais devidos à contaminação do ar, ao ruído e às vibrações, e proteger os trabalhadores contra tais riscos. Já a Convenção de no 155 , que trata do tema saúde e segurança dos trabalhadores, aborda a questão da prevenção em várias passagens. Na parte II da referida Convenção, que trata dos Princípios de uma Política Nacional, em seu art. 40, item 2, aborda-a como Princípio de Política Nacional. Na parte IV, que trata da ação em nível de empresa, no item 3 do art. 16 consta a determinação de fornecimento de equipamentos de proteção adequados a fim de prevenir os riscos de acidentes ou de efeitos prejudiciais para a saúde.

E, no que toca aos equipamentos de proteção adequados, destacam-se, na legislação trabalhista, o Equipamento de Proteção Coletiva (EPC) e o Equipamento de Proteção Individual (EPI). Os EPCs são equipamentos utilizados para proteção e segurança de um grupo de pessoas que realiza determinada tarefa ou atividade, agindo diretamente no ambiente de trabalho para eliminar/neutralizar os riscos. Já o EPI, por definição (item 6.1 da NR 6): "considera-se Equipamento de Proteção Individual (EPI), todo dispositivo ou produto de uso individual, utilizado pelo trabalhador, destinado à proteção de riscos suscetíveis de ameaçar a segurança e a saúde no trabalho ${ }^{40}$." O EPI não evita o acidente, ele tenta diminuir consequências graves ao trabalhador exposto a agentes nocivos.

\footnotetext{
40 BRASIL. Ministério do Trabalho. Portaria MTb n.0 3.214, de 08 de junho de 1978 . NR 6 Equipamento De Proteção Individual - EPI. Brasília, DF, 06 jul. 1978. Disponível em: https://www.gov.br/trabalho/pt-br/inspecao/seguranca-e-saude-no-trabalho/normasregulamentadoras/nr-06.pdf. Acesso em: 26 fev. 2021
} 
SERAFIN, Gabriela Pietsch; REUPKE, Erika Giovanini; JACOBSEN, Gilson. Inconstitucionalidade da EC 103/2019 quanto à fixação de idade mínima para a aposentadoria especial: uma abordagem à luz do direito fundamental ao meio ambiente de trabalho equilibrado. Revista Eletrônica Direito e Política, Programa de Pós-Graduação Stricto Sensu em Ciência Jurídica da UNIVALI, Itajaí, v.16, n.2, $2^{\circ}$ quadrimestre de 2021. Disponível em: www.univali.br/direitoepolitica - ISSN 1980-7791.

Portanto, percebe-se que o princípio da prevenção tem vasta aplicação no meio ambiente do trabalho, determinando a adoção de medidas que visem a evitar a ocorrência do dano, por meio de ações preventivas, buscando a proteção do homem-trabalhador: labor em um ambiente equilibrado, respeitando sua dignidade humana. E, quando não há tal possibilidade, ou seja, a eliminação por completo de desequilíbrio no meio ambiente do trabalho, a própria legislação trabalhista determina uma compensação: o adicional de insalubridade.

A legislação previdenciária, de forma similar, protege esse trabalhador sujeito a agentes nocivos através da aposentadoria especial.

\section{DO DIREITO À APOSENTADORIA ESPECIAL}

A aposentadoria especial é benefício previdenciário criado na década de 1960 com o intuito de salvaguardar a saúde e a vida do trabalhador que laborar em meio ambiente de trabalho desequilibrado, nascida, assim, em sintonia com a legislação trabalhista - proteção ao trabalhador de atividades penosas, perigosas e insalubres. A denominação "especial" deixou evidente seu caráter excepcional, adquirindo essa nomenclatura e status constitucional a partir de 1988.

Foi a Lei no 3.807, de 26 de agosto de 1960, a chamada LOPS - Lei Orgânica da Previdência Social, que garantiu a aposentação especial ao segurado que contasse com 50 (cinquenta) anos ou mais de idade, quinze anos de contribuição e tivesse trabalhado durante quinze, vinte ou vinte e cinco anos em atividades penosas, insalubres ou perigosas ${ }^{41}$. Havia também o enquadramento por categoria profissional, cujas atividades possuíam previsão absoluta de nocividade.

Regia o artigo legal:

Art. 31. A aposentadoria especial será concedida ao segurado que, contando no mínimo 50 (cinquenta) anos de idade e 15 (quinze) anos de contribuições tenha trabalhado

\footnotetext{
${ }^{41}$ BRASIL. Lei no 3.807, de 26 de agosto de 1960. Dispõe sobre a Lei Orgânica da Previdência Social. Brasília, DF: Presidência da República, 1960. Disponível em: http://www.planalto.gov.br/ccivil_03/leis/1950-1969//3807.htm. Acesso em: 26 fev. 2021.
} 
SERAFIN, Gabriela Pietsch; REUPKE, Erika Giovanini; JACOBSEN, Gilson. Inconstitucionalidade da EC 103/2019 quanto à fixação de idade mínima para a aposentadoria especial: uma abordagem à luz do direito fundamental ao meio ambiente de trabalho equilibrado. Revista Eletrônica Direito e Política, Programa de Pós-Graduação Stricto Sensu em Ciência Jurídica da UNIVALI, Itajaí, v.16, n.2, 20 quadrimestre de 2021. Disponível em: www.univali.br/direitoepolitica - ISSN 1980-7791.

durante 15(quinze), 20 (vinte) ou 25 (vinte e cinco) anos pelo menos, conforme a atividade profissional, em serviços, que, para êsse efeito, forem considerados penosos, insalubres ou perigosos, por Decreto do Poder Executivo ${ }^{42}$

A subcomissão de seguro social que elaborou a LOPS assim justificou a redução do tempo de labor para esta modalidade de benefício:

Dúvida não paira que as profissões por sua natureza penosas (como a de ferroviários, propriamente dito) ou insalubres demandam uma idade limite inferior à que normalmente é adotada nos planos de seguro-velhice. Tais misteres sujeitam o segurado a um desgaste bem mais acentuado que no comum das profissões, tornando as mais das vezes praticamente inatingível o limite normal de sessenta e cinco anos. É justo, indubitavelmente, que para tais misteres se institua um seguro velhice de caráter excepcional, com a idade limite reduzida, como terminada o artigo $2^{\circ}$ da Lei no. $593^{43}$.

Referido texto de lei da LOPS foi expressamente revogado quanto ao requisito idade pelo art. $1^{\circ}$ da Lei no 5.440-A, de 1968: "Art. 10. No art. 31 da Lei 3.807, de 26 de agosto de 1960 (Lei Orgânica da Previdência Social) suprima-se a expressão '50 (cinquenta) anos de idade ${ }^{44}$ '.

Tal requisito foi extirpado da legislação pela lei acima após Emendas apresentadas pelo Deputado Floriceno Paixão:

Justificativa de Emenda n. 1

A recente Lei no. 4.130, de 28 de fevereiro de 1962, que suprimiu o fator idade para a concessão, pelo INPS, da aposentadoria por tempo de serviço. Esqueceram-se os legisladores, entretanto, de estender a supressão ao mesmo requisito em relação à aposentadoria especial de que trata o art. 31 da Lei Orgânica da Previdência Social, pois a aposentadoria especial é considerada uma

42 BRASIL. Lei no 3.807, de 26 de agosto de 1960. Dispõe sobre a Lei Orgânica da Previdência Social. Brasília, DF: Presidência da República, 1960. Disponível em: http://www.planalto.gov.br/ccivil_03/leis/1950-1969/I3807.htm. Acesso em: 26 fev. 2021.

43 ROSA, Albino Pereira da. A lei orgânica da Previdência Social: sua interpretação e seu regulamento. Rio de Janeiro: Melso, 1960, p. 60-61.

44 BRASIL. Lei no 5.440-A, de 23 de maio de 1968. Altera o artigo 31 e dá nova redação do artigo 32 e seu $\S 1^{0}$ da Lei no 3.807, de 26 de agosto de 1960 (Lei Orgânica da Previdência Social). Brasília, DF: Presidência da República, 1968. Disponível em: http://www.planalto.gov.br/ccivil_03/leis/1950-1969/L5440a.htm. Acesso em: 26 fev. 2021 
SERAFIN, Gabriela Pietsch; REUPKE, Erika Giovanini; JACOBSEN, Gilson. Inconstitucionalidade da EC 103/2019 quanto à fixação de idade mínima para a aposentadoria especial: uma abordagem à luz do direito fundamental ao meio ambiente de trabalho equilibrado. Revista Eletrônica Direito e Política, Programa de Pós-Graduação Stricto Sensu em Ciência Jurídica da UNIVALI, Itajaí, v.16, n.2, $2^{\circ}$ quadrimestre de 2021. Disponível em: www.univali.br/direitoepolitica - ISSN 1980-7791.

aposentadoria por tempo de serviço com prazos reduzidos em razão das condições penosas, de insalubridade ou de periculosidade, sob as quais os trabalhadores exercem suas atividades. Daí deve-se com maior razão, suprimir o fator idade como um dos requisitos para a concessão da aposentadoria chamada especial.

Sala de sessões, 21.1.1968. Justificativa de Emenda n. 2

A Lei no. 4.130, de 28 de fevereiro de 1962, suprimiu por inteiro a exigência da idade (55) anos para a concessão da aposentadoria por tempo de serviço (3 ou 35 anos de serviço) na previdência social, mas o legislador se esqueceu de fazer o mesmo relativamente à aposentadoria chamada "especial", que é concedida ao "segurado que tenha trabalhado durante 15, 20 ou 25 anos, pelo menos, conforme a atividade profissional, em serviços que, para esse efeito, forem considerados penosos, insalubres e perigosos, por decreto do Poder Executivo. Como esse limite mínimo (50 anos de idade) é muito elevado, pretendemos sua alteração para 40 anos, por entender que a exigência, tal como está na lei, é altamente danosa ao trabalhador. Na verdade, se este começa a trabalhar com 18 anos, exercendo uma atividade considerada altamente perigosa ou insalubre, por exemplo, já teria direito a requerer sua aposentadoria com 33 anos, mas não pode fazê-lo precisamente porque terá que aguardar que complete 50 anos de idade, isto é, terá que trabalhar mais 17 anos para fazer jus ao benefício aposentadoria especial. Sala de sessões, 29.1.1968 45

Assevere-se que os decretos que regulamentaram a aposentadoria especial e que trouxeram as listas dos agentes agressivos para o enquadramento do tempo especial foram: o Decreto n. 53.831/64, Quadro Anexo, e o Decreto n. 83.080/79, Anexos I e II.

Com a Constituição Federal de 1988, a redação original do artigo 202, II, garantiu a aposentação com contagem de tempo inferior à aposentadoria comum para os sujeitos a trabalho sob condições especiais, aqui esclarecidos como aqueles que prejudiquem a saúde ou a integridade física, definidas em lei -

45 LADENTHIN. Adriane Bramante de Castro; SCHUSTER, Diego Henrique. Nota técnica: aposentadoria especial PEC 6/2019. [S.I.]: Instituto Brasileiro De Direito Previdenciário, 2019, p. 14-15. Disponível em: https://www.ibdp.org.br/publicidade/Nota_tecnica_aposentadoria_especial.pdf. Acesso em: 26 fev. 2021. 
SERAFIN, Gabriela Pietsch; REUPKE, Erika Giovanini; JACOBSEN, Gilson. Inconstitucionalidade da EC 103/2019 quanto à fixação de idade mínima para a aposentadoria especial: uma abordagem à luz do direito fundamental ao meio ambiente de trabalho equilibrado. Revista Eletrônica Direito e Política, Programa de Pós-Graduação Stricto Sensu em Ciência Jurídica da UNIVALI, Itajaí, v.16, n.2, 20 quadrimestre de 2021. Disponível em: www.univali.br/direitoepolitica - ISSN 1980-7791.

status constitucional à aposentadoria especial. Buscou-se, constitucionalmente, com essa definição, também, a diferenciação com o direito do trabalho (agentes perigosos, penosos e insalubres), em que pese a ligação umbilical de ambos.

Dispunha a redação original de 1988:

Art. 202. É assegurada aposentadoria, nos termos da lei, calculando-se o benefício sobre a média dos trinta e seis últimos salários de contribuição, corrigidos monetariamente mês a mês, e comprovada a regularidade dos reajustes dos salários de contribuição de modo a preservar seus valores reais e obedecidas as seguintes condições:

$[\ldots]$

II - após trinta e cinco anos de trabalho, ao homem, e, após trinta, à mulher, ou em tempo inferior, se sujeitos a trabalho sob condições especiais, que prejudiquem a saúde ou a integridade física, definidas em lei; [... ${ }^{46}$

Foi a Lei no 8.213/91, que, em seus artigos 57 e 58, trouxe a definição da aposentadoria especial. Dispõem as redações originais:

Art. 57. A aposentadoria especial será devida, uma vez cumprida a carência exigida nesta lei, ao segurado que tiver trabalhado durante 15 (quinze), 20 (vinte) ou 25 (vinte e cinco) anos, conforme a atividade profissional, sujeito a condições especiais que prejudiquem a saúde ou a integridade física.

Art. 58. A relação de atividades profissionais prejudiciais à saúde ou à integridade física será objeto de lei específica ${ }^{47}$.

As listas de categorias e agentes nocivos continuaram sendo os Decretos $\mathrm{n}$. 53.831/64 e n. 83.080/79 (ausência de lei específica afirmada no art. 58).

A Lei n. 9.032/95 modificou a aposentadoria especial, passando a exigir (a) a comprovação da atividade especial pelo segurado (seu ônus), (b) exposição de

\footnotetext{
46 BRASIL. [Constituição Federal (1988)]. Constituição da República Federativa do Brasil de 1988. Brasília, DF, 5 de outubro de 1988. Disponível em: http://www.planalto.gov.br/ccivil_03/constituicao/ConstituicaoCompilado.htm. Acesso em: 26 fev. 2021.

47 BRASIL. Lei no 8.213, de 24 de julho de 1991. Dispõe sobre os Planos de Benefícios da Previdência Social e dá outras providências. Brasília, DF, Presidência da República, 1991. Disponível em: http://www.planalto.gov.br/ccivil_03/leis//8213cons.htm. Acesso em: 26 fev. 2021.
} 
SERAFIN, Gabriela Pietsch; REUPKE, Erika Giovanini; JACOBSEN, Gilson. Inconstitucionalidade da EC 103/2019 quanto à fixação de idade mínima para a aposentadoria especial: uma abordagem à luz do direito fundamental ao meio ambiente de trabalho equilibrado. Revista Eletrônica Direito e Política, Programa de Pós-Graduação Stricto Sensu em Ciência Jurídica da UNIVALI, Itajaí, v.16, n.2, $2^{\circ}$ quadrimestre de 2021. Disponível em: www.univali.br/direitoepolitica - ISSN 1980-7791.

forma permanente aos agentes nocivos (não ocasional e não intermitente), (c) vedação de conversão de tempo comum e especial (manutenção de conversão de especial em comum) e (d) prova individualizada da exposição a agentes nocivos (exclusão de enquadramento por categoria profissional).

A Medida Provisória n. 1523-10, de 13.10.1996, modificou o critério de comprovação de atividade especial: Laudo Técnico de Condições Ambientais do Trabalho (LTCAT) para todos os agentes nocivos (antes disso apenas se exigia para ruído, frio e calor) ${ }^{48}$ e informações sobre Equipamentos de Proteção Coletiva (EPCs).

O Decreto n. 2.172, de 5.3.1997, que regulamentou a Lei n. 9.032/95 e a Medida Provisória n. 1523-10/96, revogou as listas dos Decretos 53.831/64 (tacitamente) e n. 83.080/79 (expressamente), trazendo uma nova lista de agentes nocivos em seu Anexo IV.

A Lei n. 9.528, de 10.12.1997 (conversão da MP n. 1523-10/96), mencionou pela primeira vez perfil profissiográfico (a empresa deverá elaborar e manter atualizado perfil profissiográfico abrangendo as atividades desenvolvidas pelo trabalhador e fornecer a este, quando da rescisão do contrato de trabalho, cópia autêntica desse documento, conforme $\S^{\circ}$ do art. 58) e trouxe penalidades às empresas que não mantiverem laudo técnico atualizado.

A Lei no 9.732, de 11.12.1998, criou o Adicional do SAT, destinado ao custeio da aposentadoria especial, ao introduzir no art. 57 os $\S \S 6^{\circ}$ e 70 :

$\S 600$ benefício previsto neste artigo será financiado com os recursos provenientes da contribuição de que trata o inciso II do art. 22 da Lei $n \underline{\theta} 8.212$, de 24 de julho de 1991, cujas alíquotas serão acrescidas de doze, nove ou seis pontos percentuais, conforme a atividade exercida pelo segurado a serviço da empresa permita a concessão de aposentadoria especial após quinze, vinte ou vinte e cinco anos de contribuição, respectivamente.

48 O STJ definiu, julgando o Tema 1031, em 09.12.2020, a possibilidade de comprovação de atividade especial por qualquer meio de prova até 05.03.1997, já que a regulamentação da MP se deu com o Decerto 2.172/97 (decisão ainda sem trânsito em julgado). 
SERAFIN, Gabriela Pietsch; REUPKE, Erika Giovanini; JACOBSEN, Gilson. Inconstitucionalidade da EC 103/2019 quanto à fixação de idade mínima para a aposentadoria especial: uma abordagem à luz do direito fundamental ao meio ambiente de trabalho equilibrado. Revista Eletrônica Direito e Política, Programa de Pós-Graduação Stricto Sensu em Ciência Jurídica da UNIVALI, Itajaí, v.16, n.2, $2^{\circ}$ quadrimestre de 2021. Disponível em: www.univali.br/direitoepolitica - ISSN 1980-7791.

$\S 700$ acréscimo de que trata o parágrafo anterior incide exclusivamente sobre a remuneração do segurado sujeito às condições especiais referidas no caput 49

Essa mesma lei, ainda, acrescentou parágrafos ao artigo 58 da Lei n. 8.213/91, exigindo informações sobre Equipamentos de Proteção Individual (EPI) e laudo técnico de condições ambientais do trabalho expedido por médico do trabalho ou engenheiro de segurança do trabalho nos termos da legislação trabalhista ${ }^{50}$

A Emenda Constitucional 20/98 manteve a aposentação diferenciada nos casos de atividades exercidas sob condições especiais que prejudiquem a saúde ou a integridade física, agora definidos em lei complementar (art. 201, $\$ 1^{\circ}$, redação da EC 20/1998); e a Emenda Constitucional 47/2005 incluiu essa possibilidade aos segurados portadores de deficiência (também art. 201, §10, redação da EC 47/2005).

O Decreto n. 3.048, de 06.05.1999, revogou o Decreto n. 2.172/97 e trouxe nova lista de agentes nocivos no seu Anexo IV, estando em vigor até os dias atuais: houve alterações e atualização pelos Decretos n. 4.882, de 18.11.2003, e n. 10.410 , de 30.06 .2020 .

Em que pese se tratar de benefício que mais sofreu alterações dentro do RGPS e de maior discussão judicial, haja vista a interpretação dos agentes nocivos além dos decretos, abraçando a legislação trabalhista e, muitas vezes, indo além dela (temática que este estudo não analisará), certo é que nunca se cogitou retomar a regra de idade mínima à aposentação especial, já que seu escopo é a proteção ao trabalhador exposto a agentes nocivos através de tempo menor de exposição.

Da LOPS em diante, as alterações legislativas realizadas no benefício de aposentadoria especial foram basicamente relativas à inclusão ou exclusão de atividades profissionais e de agentes agressivos considerados para a concessão

\footnotetext{
49 BRASIL. Lei no 9.732, de 11 de dezembro de 1998. Altera dispositivos das Leis nos 8.212 e 8.213, ambas de 24 de julho de 1991, da Lei no 9.317, de 5 de dezembro de 1996, e dá outras providências. Brasília, DF: Presidência da República, 1998. Disponível em: http://www.planalto.gov.br/ccivil_03/leis/l9732.htm. Acesso em: 26 fev. 2021.

50 BRASIL. Lei no 8.213, de 24 de julho de 1991. Dispõe sobre os Planos de Benefícios da Previdência Social e dá outras providências. Brasília, DF, Presidência da República, 1991. Disponível em: http://www.planalto.gov.br/ccivil_03/leis/l8213cons.htm. Acesso em: 26 fev. 2021.
} 
SERAFIN, Gabriela Pietsch; REUPKE, Erika Giovanini; JACOBSEN, Gilson. Inconstitucionalidade da EC 103/2019 quanto à fixação de idade mínima para a aposentadoria especial: uma abordagem à luz do direito fundamental ao meio ambiente de trabalho equilibrado. Revista Eletrônica Direito e Política, Programa de Pós-Graduação Stricto Sensu em Ciência Jurídica da UNIVALI, Itajaí, v.16, n.2, $2^{\circ}$ quadrimestre de 2021. Disponível em: www.univali.br/direitoepolitica - ISSN 1980-7791.

do benefício, bem como a forma de comprovação da atividade especial e sua elisão.

Foi a Proposta de Emenda Constitucional - PEC 6/2019 que resgatou a idade como pressuposto para concessão de aposentadoria especial, além de excluir a possibilidade de aposentadoria especial ante a sujeição à exposição a agentes que prejudiquem a integridade física ${ }^{51}$ :

A aposentadoria especial continua sendo garantida aos segurados filiados ao RGPS até a data de publicação desta Emenda, cujas atividades tenham sido exercidas com efetiva exposição a agentes nocivos químicos, físicos e biológicos prejudiciais à saúde, ou associação de agentes, vedada a caracterização por categoria profissional ou ocupação, considerando-se a regra de pontos, quando o total da soma resultante de sua idade e do tempo de contribuição e o tempo de efetiva exposição, para ambos os sexos, forem de: 66 pontos e 15 anos de efetiva exposição, para a aposentadoria especial de 15 anos; 76 pontos e 20 anos de efetiva exposição, para a aposentadoria especial de 20 anos; e 86 pontos e 25 anos de efetiva exposição, para a aposentadoria especial de 25 anos. A partir de janeiro de 2020, essas pontuações serão acrescidas de um ponto, até atingir 89, 93 ou 99 pontos, respectivamente, para as aposentadorias especiais de 15, 20 ou 25 anos 52

Sob o argumento de um déficit previdenciário progressivo e de questões relacionadas à demografia, a proposta de emenda à constituição, genericamente, fixou na idade mínima a solução do problema, independentemente de qual tipo de proteção essa aposentação sempre visou.

Assim, ficou tratada a EC 103/2019 na Constituição Federal - art. 201, §10:

$\S 1^{0}$ É vedada a adoção de requisitos ou critérios diferenciados para concessão de benefícios, ressalvada, nos termos de lei complementar, a possibilidade de previsão de idade e tempo de contribuição distintos da regra geral para

51 Tema que não será abordado no presente trabalho: possibilidade, após a EC, de atividade especial ante agente nocivo prejudicial à integridade física.

52 BRASIL. Câmara dos Deputados. Proposta de Emenda à Constituição no 6/2019. Modifica o sistema de previdência social, estabelece regras de transição e disposições transitórias, e dá outras providências. Brasília, 2019b, p. $59 . \quad$ Disponível em: https://www.camara.leg.br/proposicoesWeb/prop_mostrarintegra;jsessionid=node01umtuzgenk $2 \mathrm{~m}$ meweok32odj5h166459. node0?codteor=1712459\&filename=PEC+6/2019. Acesso em: 26 fev. 2021. 
SERAFIN, Gabriela Pietsch; REUPKE, Erika Giovanini; JACOBSEN, Gilson. Inconstitucionalidade da EC 103/2019 quanto à fixação de idade mínima para a aposentadoria especial: uma abordagem à luz do direito fundamental ao meio ambiente de trabalho equilibrado. Revista Eletrônica Direito e Política, Programa de Pós-Graduação Stricto Sensu em Ciência Jurídica da UNIVALI, Itajaí, v.16, n.2, $2^{\circ}$ quadrimestre de 2021. Disponível em: www.univali.br/direitoepolitica - ISSN 1980-7791.

concessão de aposentadoria exclusivamente em favor dos segurados:

I - com deficiência, previamente submetidos a avaliação biopsicossocial realizada por equipe multiprofissional e interdisciplinar;

II - cujas atividades sejam exercidas com efetiva exposição a agentes químicos, físicos e biológicos prejudiciais à saúde, ou associação desses agentes, vedada a caracterização por categoria profissional ou ocupação ${ }^{53}$.

Fica evidente, no texto da emenda, a obrigatoriedade de conjugação dos pressupostos idade e tempo de contribuição para a aposentadoria especial.

Como afirma Serau Júnior ${ }^{54}$, "a Emenda Constitucional 103/2019 mudou parcialmente o perfil constitucional da aposentadoria especial". A previsão de idade e tempo de contribuição em condições especiais, ainda que menores em relação à regra geral, são pressupostos à aposentadoria especial.

Manteve-se, pela emenda, a determinação de regulamentação da aposentadoria especial por Lei Complementar. Contudo, no art. 19, a Emenda assim dispõe:

Art. 19. $[\ldots]$

$\S 1^{0}$ Até que lei complementar disponha sobre a redução de idade mínima ou tempo de contribuição prevista nos $\S \S 1^{\circ} \mathrm{e}$ $8^{\circ}$ do art. 201 da Constituição Federal, será concedida aposentadoria:

I - aos segurados que comprovem o exercício de atividades com efetiva exposição a agentes químicos, físicos e biológicos prejudiciais à saúde, ou associação desses agentes, vedada a caracterização por categoria profissional ou ocupação, durante, no mínimo, 15 (quinze), 20 (vinte) ou 25 (vinte e cinco) anos, nos termos do disposto nos arts. 57 e 58 da Lei no 8.213, de 24 de julho de 1991, quando cumpridos:

53 BRASIL. Emenda Constitucional no 103. Altera o sistema de previdência social e estabelece regras de transição e disposições transitórias. Brasília, DF, 2019a. Disponível em: http://www.planalto.gov.br/ccivil_03/constituicao/emendas/emc/emc103.htm. Acesso em: 26 fev. 2021.

${ }^{54}$ SERAU JÚNIOR, Marco Aurélio. Comentários à lei de benefícios da previdência social: Lei 8.213/91, de 24 de julho de 1991. Curitiba: Juruá, 2020, p. 178. 
SERAFIN, Gabriela Pietsch; REUPKE, Erika Giovanini; JACOBSEN, Gilson. Inconstitucionalidade da EC 103/2019 quanto à fixação de idade mínima para a aposentadoria especial: uma abordagem à luz do direito fundamental ao meio ambiente de trabalho equilibrado. Revista Eletrônica Direito e Política, Programa de Pós-Graduação Stricto Sensu em Ciência Jurídica da UNIVALI, Itajaí, v.16, n.2, 20 quadrimestre de 2021. Disponível em: www.univali.br/direitoepolitica - ISSN 1980-7791.

a) 55 (cinquenta e cinco) anos de idade, quando se tratar de atividade especial de 15 (quinze) anos de contribuição;

b) 58 (cinquenta e oito) anos de idade, quando se tratar de atividade especial de 20 (vinte) anos de contribuição; ou

c) 60 (sessenta) anos de idade, quando se tratar de atividade especial de 25 (vinte e cinco) anos de contribuição ${ }^{55}$

E a regra de transição traz a seguinte determinação:

Art. 21. O segurado ou o servidor público federal que se tenha filiado ao Regime Geral de Previdência Social ou ingressado no serviço público em cargo efetivo até a data de entrada em vigor desta Emenda Constitucional cujas atividades tenham sido exercidas com efetiva exposição a agentes químicos, físicos e biológicos prejudiciais à saúde, ou associação desses agentes, vedada a caracterização por categoria profissional ou ocupação, desde que cumpridos, no caso do servidor, o tempo mínimo de 20 (vinte) anos de efetivo exercício no serviço público e de 5 (cinco) anos no cargo efetivo em que for concedida a aposentadoria, na forma dos arts. 57 e 58 da Lei no 8.213, de 24 de julho de 1991, poderão aposentar-se quando o total da soma resultante da sua idade e do tempo de contribuição e o tempo de efetiva exposição forem, respectivamente, de:

I - 66 (sessenta e seis) pontos e 15 (quinze) anos de efetiva exposição;

II - 76 (setenta e seis) pontos e 20 (vinte) anos de efetiva exposição; e

III - 86 (oitenta e seis) pontos e 25 (vinte e cinco) anos de efetiva exposição ${ }^{56}$

Quanto à fixação da idade mínima à aposentadoria especial, justificou o relator Deputado Samuel Moreira:

\footnotetext{
55 BRASIL. Emenda Constitucional no 103. Altera o sistema de previdência social e estabelece regras de transição e disposições transitórias. Brasília, DF, 2019a. Disponível em: http://www.planalto.gov.br/ccivil_03/constituicao/emendas/emc/emc103.htm. Acesso em: 26 fev. 2021.

56 BRASIL. Emenda Constitucional no 103. Altera o sistema de previdência social e estabelece regras de transição e disposições transitórias. Brasília, DF, 2019a. Disponível em: http://www.planalto.gov.br/ccivil_03/constituicao/emendas/emc/emc103.htm. Acesso em: 26 fev. 2021.
} 
SERAFIN, Gabriela Pietsch; REUPKE, Erika Giovanini; JACOBSEN, Gilson. Inconstitucionalidade da EC 103/2019 quanto à fixação de idade mínima para a aposentadoria especial: uma abordagem à luz do direito fundamental ao meio ambiente de trabalho equilibrado. Revista Eletrônica Direito e Política, Programa de Pós-Graduação Stricto Sensu em Ciência Jurídica da UNIVALI, Itajaí, v.16, n.2, $2^{\circ}$ quadrimestre de 2021. Disponível em: www.univali.br/direitoepolitica - ISSN 1980-7791.

Enquanto não editada lei complementar, para os trabalhadores que exercem atividades prejudiciais à saúde, foram adotadas as idades mínimas sugeridas na PEC, fixadas em 55, 58 e 60 anos, conforme grau de prejuízo à saúde, combinada com o tempo mínimo de contribuição e de exposição ao agente nocivo. Entendemos que estes trabalhadores precisam ser afastados da atividade nociva, mas podem e devem ser realocados em outras funções. Ressalte-se que a grande maioria daqueles que hoje se aposentam sem limite de idade nestas condições, alguns até mesmo antes dos 40 anos de idade, retornam ao mercado de trabalho, pois possuem condições de se manterem na ativa, desde que em atividade diversa. Como premissa, adotamos que nenhum trabalhador, excetuado a pessoa com deficiência, deve se aposentar antes dos 55 anos de idade. Adotamos esta premissa, pois sabemos que antes da referida idade há capacidade para manter a atividade produtiva e que não é razoável sobrecarregar as novas gerações. Caso, no entanto, seja constatado que faltam condições para o trabalho, o segurado terá acesso a aposentadoria por incapacidade permanente, sem limite etário ${ }^{57}$

Portanto, ainda que se fale em tempo possível à aposentação diminuto, claro que esse tempo poderá ser aumentado ante a exigência de idade mínima.

Como, por exemplo, o mineiro de subsolo, frente de trabalho - escavação, que poderá aposentar-se com 15 anos de labor nessas condições (Anexo IV, código agente nocivo 4.0.2, Decreto 3.048/99). Partindo-se do início desse labor aos 20 anos de idade, sem interrupção em contrato de trabalho, haveria possibilidade de aposentação, pré-emenda constitucional, aos 35 anos de idade. Pelo regramento permanente vigente, deverá esperar até seus 55 anos de idade. Ou seja, se na mesma atividade, mais 20 anos em condições especiais - nocivas à saúde do trabalhador.

Sempre é bom lembrar que a aposentadoria especial, ao traçar o limitador de tempo de exposição a agentes nocivos, não o faz livremente, mas analisando as condições epidemiológicas de exposição aos agentes agressivos de saúde,

57 BRASIL. Câmara dos Deputados. Parecer à Proposta de Emenda Constitucional No 6, de 2019. Relator: Deputado Samuel Moreira. Brasília, DF, 13 jul. 2019. Disponível em: https://www.camara.leg.br/proposicoesWeb/prop mostrarintegra?codteor $=1764374 \&$ filename $=\mathrm{Par}$ ecer-PEC00619-13-06-2019, p. 76-77. Acesso em: 26 fev. 2021. 
SERAFIN, Gabriela Pietsch; REUPKE, Erika Giovanini; JACOBSEN, Gilson. Inconstitucionalidade da EC 103/2019 quanto à fixação de idade mínima para a aposentadoria especial: uma abordagem à luz do direito fundamental ao meio ambiente de trabalho equilibrado. Revista Eletrônica Direito e Política, Programa de Pós-Graduação Stricto Sensu em Ciência Jurídica da UNIVALI, Itajaí, v.16, n.2, 20 quadrimestre de 2021. Disponível em: www.univali.br/direitoepolitica - ISSN 1980-7791.

buscando a garantia da saúde e da vida do trabalhador - caráter eminentemente protetivo.

Nas palavras de Castro e Lazzari 58 :

A aposentadoria especial é uma espécie de aposentadoria por tempo de contribuição, com redução de tempo necessário à inativação, concedida em razão de exercício de atividades consideradas prejudiciais à saúde ou à integridade física. Ou seja, é um benefício de natureza previdenciária que se presta a reparar financeiramente 0 trabalhador sujeito a condições de trabalho inadequadas.

Acerca da finalidade e do fundamento do benefício, esmiúça Maria Lúcia Luz Leira ${ }^{59}$

A finalidade do benefício de aposentadoria especial é de amparar o trabalhador que laborou em condições nocivas e perigosas à sua saúde, reduzindo 0 tempo de serviço/contribuição para fins de aposentadoria. Tem, pois, como fundamento o trabalho desenvolvido em atividades ditas insalubres. Pela legislação de regência, a condição, o pressuposto determinante do benefício está ligado à presença de agentes perigosos ou nocivos (químicos, físicos e biológicos) à saúde ou à integridade física do trabalhador, e não apenas àquelas atividades ou funções catalogadas em regulamento.

Sérgio Pinto Martins ${ }^{60}$ também discorre sobre a aposentadoria especial e registra importante distinção:

Aposentadoria especial é o benefício previdenciário decorrente do trabalho realizado em condições prejudiciais à saúde ou à integridade física do segurado, de acordo com a previsão da lei. Trata-se de um benefício de natureza extraordinária, tendo por objetivo compensar o trabalho do segurado que presta serviços em condições adversas à sua saúde ou que desempenha atividades com riscos superiores aos normais.

58 CASTRO, Carlos Alberto Pereira de; LAZZARI, João Batista. Manual de direito previdenciário. 16 ed. Rio de Janeiro: Forense, 2017, p. 719.

59 LEIRA, Maria Lúcia Luz. Direito previdenciário e estado democrático de direito: (re)discussão à luz da hermenêutica. Porto Alegre: Livraria do Advogado, 2001, p. 164.

60 MARTINS, Sérgio Pinto. Direito da Seguridade Social. 35 ed.São Paulo: Atlas, 2015, p. 374. 
SERAFIN, Gabriela Pietsch; REUPKE, Erika Giovanini; JACOBSEN, Gilson. Inconstitucionalidade da EC 103/2019 quanto à fixação de idade mínima para a aposentadoria especial: uma abordagem à luz do direito fundamental ao meio ambiente de trabalho equilibrado. Revista Eletrônica Direito e Política, Programa de Pós-Graduação Stricto Sensu em Ciência Jurídica da UNIVALI, Itajaí, v.16, n.2, $2^{\circ}$ quadrimestre de 2021. Disponível em: www.univali.br/direitoepolitica - ISSN 1980-7791.

A aposentadoria especial é espécie de aposentadoria por tempo de contribuição. Não é espécie de aposentadoria por invalidez, pois não compreende invalidez.

Difere, também, a aposentadoria especial da aposentadoria por invalidez, pois nesta o fato gerador é a incapacidade para o trabalho e na aposentadoria especial esse fato inexiste. A aposentadoria especial pressupõe agressão à saúde do trabalhador por meio de exposição a agentes nocivos. A segunda decorre de incapacidade $e$ insusceptibilidade de reabilitação do segundo. O aposentado de forma especial não fica inválido para o trabalho, apenas não pode exercer atividade que o exponha a agentes nocivos à saúde.

Defere-se a aposentadoria especial quando o segurado tenha laborado em atividades sujeitas a condições especiais que prejudiquem sua saúde e integridade física.

Independentemente do conceito ou do doutrinador a que se recorra, é certo que, em todos eles, uma constatação se repete: a aposentadoria especial ostenta um nítido caráter protetivo. Trata-se, a toda evidência, de um benefício previdenciário concedido para preservar a saúde, o bem-estar e a integridade do trabalhador submetido rotineiramente a condições de trabalho especiais. Portanto, não há dúvidas do necessário afastamento do trabalhador da atividade nociva antes que ele venha a se tornar incapaz ao labor: caráter protetivo da aposentadoria especial.

Dito isso, pergunta-se: haverá eficácia da norma protetiva de preservação da saúde, a qual tem direta relação com a preservação da vida e com o princípio da dignidade humana, fixando-se idade mínima à sua fruição? 
SERAFIN, Gabriela Pietsch; REUPKE, Erika Giovanini; JACOBSEN, Gilson. Inconstitucionalidade da EC 103/2019 quanto à fixação de idade mínima para a aposentadoria especial: uma abordagem à luz do direito fundamental ao meio ambiente de trabalho equilibrado. Revista Eletrônica Direito e Política, Programa de Pós-Graduação Stricto Sensu em Ciência Jurídica da UNIVALI, Itajaí, v.16, n.2, $2^{\circ}$ quadrimestre de 2021. Disponível em: www.univali.br/direitoepolitica - ISSN 1980-7791.

\section{DO JULGAMENTO DO TEMA 709 DO SUPREMO TRIBUNAL FEDERAL: CONSTITUCIONALIDADE DO ART. 57, §8०, DA LEI No 8.213/91 - IMPOSSIBILIDADE DE PERCEPÇÃO DO BENEFÍCIO DE APOSENTADORIA ESPECIAL INDEPENDENTEMENTE DO AFASTAMENTO DO BENEFICIÁRIO DAS ATIVIDADES LABORAIS NOCIVAS A SUA SAÚDE}

O STF foi levado a analisar a constitucionalidade da norma legal de afastamento da atividade especial daqueles aposentados em atividade especial - $\S 8^{\circ}$ do art. 57 da Lei 8.213/91, porquanto o Tribunal Regional Federal da 4a Região - TRF4 afastou a sua incidência ao argumento de impedimento ao livre exercício do trabalho, no julgamento do Incidente de Arguição de Inconstitucionalidade 5001401-77.2012.4004.0000, Corte Especial do TRF4, de relatoria do Des. Fed. Ricardo Teixeira do Valle Pereira, em 24.05.2012.

O INSS, nas razões do recurso extraordinário, afirmou que o afastamento compulsório teria amparo no dever do Estado de evitar que o trabalhador continue, deliberadamente, prejudicando sua saúde e sua integridade física após se aposentar em atividade que demande ambas - caráter protetivo do benefício em apreço.

O STF afirmou a constitucionalidade na norma nos seguintes termos:

[...] $\mathrm{O}$ art. 57, $\S 8^{\circ}$, da Lei $\mathrm{n}^{\circ} 8.213 / 91$ é constitucional, inexistindo qualquer tipo de conflito entre ele e os arts. 50, inciso XIII; 70, inciso XXXIII; e 201, § 10, da Lei Fundamental. A norma se presta, de forma razoável e proporcional, para homenagear o princípio da dignidade da pessoa humana, bem como os direitos à saúde, à vida, ao ambiente de trabalho equilibrado e à redução dos riscos inerentes ao trabalho. $[\ldots]^{61}$

Retira-se do voto condutor do acórdão:

\footnotetext{
61 BRASIL. Supremo Tribunal Federal. Recurso extraordinário 791.961 Paraná. Relator: Min. Dias Toffoli, 08 junho 2020, p. 01.0 Disponível em: http://redir.stf.jus.br/paginadorpub/paginador.jsp?docTP $=T P \& d o c I D=753515290$. Acesso em: 26 fev. 2021.
} 
SERAFIN, Gabriela Pietsch; REUPKE, Erika Giovanini; JACOBSEN, Gilson. Inconstitucionalidade da EC 103/2019 quanto à fixação de idade mínima para a aposentadoria especial: uma abordagem à luz do direito fundamental ao meio ambiente de trabalho equilibrado. Revista Eletrônica Direito e Política, Programa de Pós-Graduação Stricto Sensu em Ciência Jurídica da UNIVALI, Itajaí, v.16, n.2, $2^{\circ}$ quadrimestre de 2021. Disponível em: www.univali.br/direitoepolitica - ISSN 1980-7791.

[...] a aposentação se dá de forma precoce porque o legislador presume que, em virtude da nocividade das atividades desempenhadas, o trabalhador sofrerá um desgaste maior do que o normal de sua saúde. Dito em outras palavras, o tempo para aposentadoria é reduzido em relação às outras categorias porque, ante a natureza demasiado desgastante e/ou extenuante do serviço executado, entendeu-se por bem que o exercente de atividade especial deva laborar por menos tempo - seria essa uma forma de compensá-lo e, sobretudo, de protegêlo.

Ora, se a presunção de incapacidade é, consoante dito, absoluta; se a finalidade da instituição do benefício em questão é, em essência, resguardar a saúde e o bem-estar do trabalhador que desempenha atividade especial; se o intuito da norma, ao possibilitar a ele a aposentadoria antecipada, é justamente retirá-lo do ambiente insalubre e prejudicial a sua incolumidade física, a fim de que não tenha sua integridade severa e irremediavelmente afetada, qual seria o sentido de se permitir que o indivíduo perceba a aposentadoria especial mas continue a desempenhar atividade nociva? Como se nota, sob essa óptica, a previsão do art. 57, $\S 80$, da Lei no 8.213/91, é absolutamente razoável e consentânea com a vontade do legislador.

Desarrazoado, ilógico e flagrantemente contrário à ideia que guiou a instituição do benefício é, justamente, permitir o retorno ao labor especial ou sua continuidade após a obtenção da aposentadoria - prática que contraria em tudo o propósito do benefício e que significa ferir de morte sua razão de $\operatorname{ser}^{62}$

O STF, através do voto condutor do acórdão, deixa claro que a finalidade da lei é a proteção à saúde, à integridade física e ao bem-estar do obrador:

Ao prestigiar a saúde, a disposição legal prestigia também o direito à vida, intrinsecamente ligado ao primeiro, visto que reforçar a necessidade de afastamento da atividade especial implica não só mitigar a chance de desenvolvimento de doenças ocupacionais capazes de levar à incapacidade definitiva e, eventualmente, à morte, mas também reduzir a probabilidade de o indivíduo vir a se lesionar ou mesmo a falecer em algum acidente de trabalho (uma vez que, não

\footnotetext{
62 BRASIL. Supremo Tribunal Federal. Recurso extraordinário 791.961 Paraná. Relator: Min. Dias Toffoli, 08 junho 2020, p. 11. Disponível em: http://redir.stf.jus.br/paginadorpub/paginador.jsp?docTP $=T P \& d o c I D=753515290$. Acesso em: 26 fev. 2021.
} 
SERAFIN, Gabriela Pietsch; REUPKE, Erika Giovanini; JACOBSEN, Gilson. Inconstitucionalidade da EC 103/2019 quanto à fixação de idade mínima para a aposentadoria especial: uma abordagem à luz do direito fundamental ao meio ambiente de trabalho equilibrado. Revista Eletrônica Direito e Política, Programa de Pós-Graduação Stricto Sensu em Ciência Jurídica da UNIVALI, Itajaí, v.16, n.2, $2^{\circ}$ quadrimestre de 2021. Disponível em: www.univali.br/direitoepolitica - ISSN 1980-7791.

raro, o próprio local de trabalho descortina-se perigoso e propício à ocorrência de intercorrências graves) ${ }^{63}$

Dito isso, não pairam dúvidas que o STF entende que o objetivo do meio ambiente do trabalho e da seguridade social é manter o trabalhador em atividade especial (meio ambiente agressivo à sua saúde) apenas pelo lapso temporal necessário à aposentação, já que vetou a continuidade em labor especial após isso, como proteção ao trabalhador.

\section{APOSENTADORIA ESPECIAL: DESCONSTITUIÇÃO INCONSTITUCIONAL DE UM DIREITO}

A proteção à saúde foi contemplada na Constituição Federal quando trata dos fundamentos do Estado Democrático de Direito (art. 10, III, da CF) e do respeito aos direitos humanos (art. 40, II, da CF). A proteção à vida, no caput do art. $5^{\circ}$ da Constituição Federal, deixa claro que a saúde, apesar de não prevista naquele artigo, deve sempre ser respeitada, mormente porque, quando trata dos Direitos Sociais, afirma a proteção à vida e à saúde do trabalhador (arts. 60, caput e 70, XXII, da CF). Ainda, em seu capítulo da Ordem Social, a Constituição afirma que a saúde é direito de todos e dever do Estado (art. 196).

A inserção do direito à saúde dentre os direitos fundamentais sociais é decisiva para sua configuração, pois Ihe confere aplicabilidade imediata e impede que sua concretização dependa das vontades e da volatilidade do legislador ordinário. Aliás, além da fundamentalidade formal, relacionada à sua localização topológica dentro do texto constitucional, o direito à saúde também é dotado de uma fundamentalidade material, pois é condição indispensável para a garantia dos valores defendidos na ordem constitucional brasileira: a dignidade humana. Ainda, o direito à saúde abrange tanto um caráter positivo quanto outro negativo: este resta consubstanciado na faculdade de se exigir que o Estado se abstenha de qualquer ato ofensivo a tal direito.

63 BRASIL. Supremo Tribunal Federal. Recurso extraordinário 791.961 Paraná. Relator: Min. Dias Toffoli, 08 junho 2020, p. 23 Disponível em: http://redir.stf.jus.br/paginadorpub/paginador.jsp?docTP=TP\&docID=753515290. Acesso em: 26 fev. 2021. 
SERAFIN, Gabriela Pietsch; REUPKE, Erika Giovanini; JACOBSEN, Gilson. Inconstitucionalidade da EC 103/2019 quanto à fixação de idade mínima para a aposentadoria especial: uma abordagem à luz do direito fundamental ao meio ambiente de trabalho equilibrado. Revista Eletrônica Direito e Política, Programa de Pós-Graduação Stricto Sensu em Ciência Jurídica da UNIVALI, Itajaí, v.16, n.2, $2^{\circ}$ quadrimestre de 2021. Disponível em: www.univali.br/direitoepolitica - ISSN 1980-7791.

Para Gebran Neto e Schulz ${ }^{64}$, essa dimensão objetiva impõe ao Estado tríplices deveres relacionados à saúde, ou seja: (a) dever de respeito, não podendo o poder público violar o direito à saúde; (b) dever de proteção, devendo o Estado adotar medidas que impeçam terceiros de violar o direito à saúde; e (c) dever de prestação, que impõe ao Estado o provimento dos meios materiais necessários ao exercício desse direito. Obviamente, esses deveres relacionados à dimensão objetiva do direito à saúde repercutem em sua dimensão subjetiva, pois permitem que os titulares desse direito possam exigi-lo em caso de violação do direito fundamental.

A aposentadoria especial, como antes afirmado, ao traçar o limitador de tempo de exposição a agentes nocivos, não o faz livremente, mas levando em conta as condições epidemiológicas de exposição aos agentes agressivos à saúde, buscando a garantia da saúde e da vida do trabalhador - caráter eminentemente protetivo, como bem afirmou o STF na análise do Tema 709: afastamento da atividade nociva antes de seu adoecimento.

Certo é que a ciência, observada a evolução, poderá, a qualquer momento, verificar a possibilidade de maior tempo de exposição a determinado agente (aumento de tempo à aposentação) ou, até, excluir determinado agente nocivo (verificação de que não mais o é), o que justifica a modificação de análise da atividade especial.

Contudo, sem justificação científica e simplesmente baseada em análises econômicas, financeiras ou demográficas, a manutenção do trabalhador em atividade nociva à sua saúde, até o cômputo de idade em tempo superior ao exigido para a aposentação, é violação à proteção de sua saúde e de sua vida. Em outras palavras, trata-se de desconstituição inconstitucional de um direito.

${ }^{64}$ GEBRAN NETO, João Pedro; SCHULZE, Clenio Jair. Direito à saúde: análise à luz da judicialização. Porto Alegre: Verbo Jurídico, 2015, p. 38. 
SERAFIN, Gabriela Pietsch; REUPKE, Erika Giovanini; JACOBSEN, Gilson. Inconstitucionalidade da EC 103/2019 quanto à fixação de idade mínima para a aposentadoria especial: uma abordagem à luz do direito fundamental ao meio ambiente de trabalho equilibrado. Revista Eletrônica Direito e Política, Programa de Pós-Graduação Stricto Sensu em Ciência Jurídica da UNIVALI, Itajaí, v.16, n.2, $2^{\circ}$ quadrimestre de 2021. Disponível em: www.univali.br/direitoepolitica - ISSN 1980-7791.

A jurisprudência atual do Supremo Tribunal Federal é pacífica no sentido de que normas constitucionais inconstitucionais são passíveis de controle de constitucionalidade em relação ao poder constituinte derivado ${ }^{65}$.

Em reforço, invoca-se o ensinamento de Jorge Miranda ${ }^{66}$

Pode haver inconstitucionalidade por oposição entre normas constitucionais preexistentes e normas constitucionais supervenientes, na medida em que a validade destas decorre daquelas; não por oposição entre normas feitas ao mesmo tempo por uma mesma autoridade jurídica. Pode haver inconstitucionalidade da revisão constitucional, porque a revisão funda-se, formal e materialmente, na Constituição; não pode haver inconstitucionalidade da Constituição.

Além disso, no caso em análise, a Emenda Constitucional 103/2009 viola a proibição inserta no art. $60, \S 4^{\circ}$, da Constituição Federal, ou seja, afronta cláusula pétrea ao ferir a preservação da vida, da saúde e o princípio da dignidade humana do trabalhador com direito à aposentadoria especial.

E isso é extremamente grave do ponto de vista da unidade da ordem jurídica, pois, para o Supremo, as cláusulas pétreas protegem a essência da Constituição, seus princípios mais importantes, visando a garantir sua estabilidade.

Assim, o debate constitucional de hoje não se circunscreve mais à possibilidade ou não de controle de constitucionalidade de uma Emenda Constitucional, já que a Corte Suprema solucionou o conflito no sentido de que sim, mas ao conteúdo e à extensão da cláusula pétrea que restou ferida com a Emenda Constitucional $103 / 2019$, conforme demonstrado nesse estudo.

\section{CONSIDERAÇÕES FINAIS}

A evolução legislativa e científica (higiene do trabalhador) apontou para a necessidade de aposentação "precoce" aos trabalhadores expostos a um meio

65 Adin 2.024-2/DF.

66 MIRANDA, Jorge de. Manual de direito constitucional. Coimbra: Coimbra Editora, 1981. v. 1/ t. 2 , p. 586 . 
SERAFIN, Gabriela Pietsch; REUPKE, Erika Giovanini; JACOBSEN, Gilson. Inconstitucionalidade da EC 103/2019 quanto à fixação de idade mínima para a aposentadoria especial: uma abordagem à luz do direito fundamental ao meio ambiente de trabalho equilibrado. Revista Eletrônica Direito e Política, Programa de Pós-Graduação Stricto Sensu em Ciência Jurídica da UNIVALI, Itajaí, v.16, n.2, $2^{\circ}$ quadrimestre de 2021. Disponível em: www.univali.br/direitoepolitica - ISSN 1980-7791.

ambiente de trabalho desequilibrado à preservação da vida e da saúde princípios constitucionais.

A Emenda Constitucional 103/2019, contudo, trouxe significativas mudanças à concessão de benefícios previdenciários; dentre elas, criou um pressuposto a mais para a concessão da aposentadoria especial: a idade mínima.

Restou respondida a indagação deste estudo, no sentido de que, ao se obrigar que o trabalhador exposto a agentes agressivos à saúde suporte tempo superior ao exigido pela lei (25, 20 ou 15 anos), para fins de completar a idade mínima redação dada pela Emenda Constitucional 103/2019 -, há nítida afronta à norma constitucional originária de proteção à vida, à saúde e ao meio ambiente de trabalho equilibrado.

Para além das delimitações metodológicas e das questões ainda abertas sobre o tema, que poderão ser superadas em próximas abordagens, a intervenção estatal - aqui através de emenda à Constituição -, ainda que pautada em fundamentos econômicos, financeiros ou democráticos, não pode atingir direito fundamental há muito assegurado.

\section{REFERÊNCIAS DAS FONTES CITADAS}

ABRAMOVICH, Victor; COURTIS, Christian. Los derechos sociales como derechos exigibles. Madrid: Trotta, 2002.

ALMEIDA, Gabriel Schroeder de. Controle de constitucionalidade de emendas constitucionais: o conceito de cláusula pétrea nos votos dos ministros do Supremo Tribunal Federal. 2019. Monografia (Pós-graduação em Direito Público) - Escola de Formação da Sociedade Brasileira de Direito Público, São Paulo, 2019.

BOBBIO, Norberto. A era dos direitos. Tradução de: Carlos Nelson Coutinho. Rio de Janeiro: Campus, 1992.

BONAVIDES, Paulo. Do Estado Liberal ao Estado Social: $7^{a}$ ed. São Paulo: Malheiros, 2004. 
SERAFIN, Gabriela Pietsch; REUPKE, Erika Giovanini; JACOBSEN, Gilson. Inconstitucionalidade da EC 103/2019 quanto à fixação de idade mínima para a aposentadoria especial: uma abordagem à luz do direito fundamental ao meio ambiente de trabalho equilibrado. Revista Eletrônica Direito e Política, Programa de Pós-Graduação Stricto Sensu em Ciência Jurídica da UNIVALI, Itajaí, v.16, n.2, $2^{\circ}$ quadrimestre de 2021. Disponível em: www.univali.br/direitoepolitica - ISSN 1980-7791.

BRASIL. [Constituição Federal (1988)]. Constituição da República Federativa do Brasil de 1988. Brasília, DF, 5 de outubro de 1988. Disponível em: http://www.planalto.gov.br/ccivil_03/constituicao/ConstituicaoCompilado.htm.

Acesso em: 26 fev. 2021.

BRASIL. Decreto-Lei no 5.452 , de $1^{\circ}$ de maio de 1943. Aprova a Consolidação das Leis do Trabalho. Rio de Janeiro, 01 mai. 1943. Disponível em: http://www.planalto.gov.br/ccivil_03/Decreto-Lei/Del5452.htm. Acesso em: 26 fev. 2021.

BRASIL. Emenda Constitucional no 103. Altera o sistema de previdência social e estabelece regras de transição e disposições transitórias. Brasília, DF, 2019a. Disponível em: http://www.planalto.gov.br/ccivil_03/constituicao/emendas/emc/emc103.htm. Acesso em: 26 fev. 2021.

BRASIL. Lei no 3.807, de 26 de agosto de 1960. Dispõe sobre a Lei Orgânica da Previdência Social. Brasília, DF: Presidência da República, 1960. Disponível em: http://www.planalto.gov.br/ccivil_03/leis/1950-1969/I3807.htm. Acesso em: 26 fev. 2021.

BRASIL. Lei no 5.440-A, de 23 de maio de 1968. Altera o artigo 31 e dá nova redação do artigo 32 e seu $\S 1^{0}$ da Lei no 3.807, de 26 de agosto de 1960 (Lei Orgânica da Previdência Social). Brasília, DF: Presidência da República, 1968. Disponível em: http://www.planalto.gov.br/ccivil_03/leis/1950-1969/L5440a.htm. Acesso em: 26 fev. 2021.

BRASIL. Lei no 8.213, de 24 de julho de 1991. Dispõe sobre os Planos de Benefícios da Previdência Social e dá outras providências. Brasília, DF, Presidência da República, 1991. Disponível em: http://www.planalto.gov.br/ccivil_03/leis//8213cons.htm. Acesso em: 26 fev. 2021.

BRASIL. Lei no 9.732, de 11 de dezembro de 1998. Altera dispositivos das Leis nos 8.212 e 8.213, ambas de 24 de julho de 1991, da Lei no 9.317, de 5 de dezembro de 1996, e dá outras providências. Brasília, DF: Presidência da República, $1998 . \quad$ Disponível em: http://www.planalto.gov.br/ccivil_03/leis//9732.htm. Acesso em: 26 fev. 2021.

BRASIL. Câmara dos Deputados. Parecer à Proposta de Emenda Constitucional No 6, de 2019. Relator: Deputado Samuel Moreira. Brasília, DF, 13 jul. 2019. Disponível em: https://www.camara.leg.br/proposicoesWeb/prop_mostrarintegra?codteor $=1764$ 374\&filename=Parecer-PEC00619-13-06-2019. Acesso em: 26 fev. 2021. 
SERAFIN, Gabriela Pietsch; REUPKE, Erika Giovanini; JACOBSEN, Gilson. Inconstitucionalidade da EC 103/2019 quanto à fixação de idade mínima para a aposentadoria especial: uma abordagem à luz do direito fundamental ao meio ambiente de trabalho equilibrado. Revista Eletrônica Direito e Política, Programa de Pós-Graduação Stricto Sensu em Ciência Jurídica da UNIVALI, Itajaí, v.16, n.2, $2^{\circ}$ quadrimestre de 2021. Disponível em: www.univali.br/direitoepolitica - ISSN 1980-7791.

BRASIL. Ministério do Trabalho. Portaria MTb n. ${ }^{0} 3.214$, de 08 de junho de 1978. NR 6 - Equipamento De Proteção Individual - EPI. Brasília, DF, 06 jul. 1978. Disponível em: https://www.gov.br/trabalho/pt-br/inspecao/seguranca-e-saudeno-trabalho/normas-regulamentadoras/nr-06.pdf. Acesso em: 26 fev. 2021.

BRASIL. Câmara dos Deputados. Proposta de Emenda à Constituição no 6/2019. Modifica o sistema de previdência social, estabelece regras de transição e disposições transitórias, e dá outras providências. Brasília, 2019b. Disponível em:

https://www.camara.leg.br/proposicoesWeb/prop_mostrarintegra;jsessionid=nod e01umtuzgenk2mmeweok32odj5h166459. node0?codteor $=1712459$ \&filename $=P$ EC+6/2019. Acesso em: 26 fev. 2021.

BRASIL. Supremo Tribunal Federal. Recurso extraordinário 791.961 Paraná. Relator: Min. Dias Toffoli, 08 junho 2020. Disponível em: http://redir.stf.jus.br/paginadorpub/paginador.jsp?docTP=TP\&docID $=753515290$. Acesso em: 26 fev. 2021.

BRASIL. Supremo Tribunal Federal. Ação Direta de Inconstitucionalidade n. 815. Relator: Min. Moreira Alves, 28 março 1996. Disponível em: http://redir.stf.jus.br/paginadorpub/paginador.jsp?docTP=AC\&docID $=266547$.

Acesso em: 26 fev. 2021.

CANOTILHO, Joaquim José Gomes. Estudos sobre direitos fundamentais: o direito ao ambiente como direito subjetivo. Rio de Janeiro: Revista dos Tribunais, 2008.

CASTRO, Carlos Alberto Pereira de; LAZZARI, João Batista. Manual de direito previdenciário. 16 ed. Rio de Janeiro: Forense, 2017.

CRUZ, Paulo Márcio. Política, poder, ideologia e Estado contemporâneo. 3. ed. 1. tir. Curitiba: Juruá, 2003.

DANTAS, Marcelo Buzaglo; BONISSONI, Natammy Luana de Aguiar; FERRER, Gabriel Real. O Processo de Internacionalização da Proteção Ambiental e dos Direitos Humanos. In: GARCIA, Denise Schmitt Siqueira; DANTAS, Marcelo Buzaglo; GIMENEZ, Andrés Molina (Org.). Sociedade, Governança e Meio Ambiente [recurso eletrônico]. 1 ed. Itajaí: UNIVALI, 2017 (Coleção Estado, transnacionalidade e sustentabilidade; t. 3). Disponível em: https://www.univali.br/vida-no-campus/editora-univali/ebooks/Documents/ecjs/Ebook $\% 202017 \% 20$ SOCIEDADE, \%20GOVERNAN\%C3\%87A\%20E\%20MEIO\%20A MBIENTE\%20\%E2\%80\%93\%20TOMO\%2003.pdf. Acesso em: 22 mar. 2021.

DERANI, Cristiane. Direito ambiental econômico. São Paulo: Saraiva, 2008. 
SERAFIN, Gabriela Pietsch; REUPKE, Erika Giovanini; JACOBSEN, Gilson. Inconstitucionalidade da EC 103/2019 quanto à fixação de idade mínima para a aposentadoria especial: uma abordagem à luz do direito fundamental ao meio ambiente de trabalho equilibrado. Revista Eletrônica Direito e Política, Programa de Pós-Graduação Stricto Sensu em Ciência Jurídica da UNIVALI, Itajaí, v.16, n.2, $2^{\circ}$ quadrimestre de 2021. Disponível em: www.univali.br/direitoepolitica - ISSN 1980-7791.

GARCIA-PELAYO, Manuel. As transformações do Estado contemporâneo. Tradução de Agassiz Almeida Filho. Rio de Janeiro: Forense, 2009.

GEBRAN NETO, João Pedro; SCHULZE, Clenio Jair. Direito à saúde: análise à luz da judicialização. Porto Alegre: Verbo Jurídico, 2015.

HERRERA FLORES, Joaquin. A (re)invenção dos direitos humanos. Florianópolis: Fundação Boiteux, 2009.

LADENTHIN. Adriane Bramante de Castro; SCHUSTER, Diego Henrique. Nota técnica: aposentadoria especial PEC 6/2019. [S.I.]: Instituto Brasileiro De Direito Previdenciário, 2019. Disponível em: https://www.ibdp.org.br/publicidade/Nota_tecnica_aposentadoria_especial.pdf. Acesso em: 26 fev. 2021.

LEIRA, Maria Lúcia Luz. Direito previdenciário e estado democrático de direito: (re)discussão à luz da hermenêutica. Porto Alegre: Livraria do Advogado, 2001.

MARTINS, Sérgio Pinto. Direito da Seguridade Social. 35 ed.São Paulo: Atlas, 2015.

MELO, Raimundo Simão de. Direito ambiental do trabalho e a saúde do trabalhador. 5. ed. São Paulo: LTr, 2013.

MIRANDA, Jorge de. Manual de direito constitucional. Coimbra: Coimbra Editora, 1981. v. 1/ t. 2.

NOVAIS, Jorge Reis. Contributo para uma teoria do Estado de direito: do Estado de direito liberal ao Estado social e democrático de direito. Coimbra: Almedina, 2006.

PADILHA, Norma Sueli. Do meio ambiente do trabalho equilibrado. São Paulo: LTr, 2002.

ROCHA, Daniel Machado da. O direito fundamental à previdência social. Porto Alegre: Livraria do Advogado, 2004.

RODRIGUES, Marcelo Abelha. Elementos de direito ambiental: parte geral. São Paulo: Revista dos Tribunais, 2005.

ROSA, Albino Pereira da. A lei orgânica da Previdência Social: sua interpretação e seu regulamento. Rio de Janeiro: Melso, 1960.

SARLET, Ingo Wolfgang. A eficácia dos direitos fundamentais. 10. ed. Porto Alegre: Livraria do Advogado, 2011. 
SERAFIN, Gabriela Pietsch; REUPKE, Erika Giovanini; JACOBSEN, Gilson. Inconstitucionalidade da EC 103/2019 quanto à fixação de idade mínima para a aposentadoria especial: uma abordagem à luz do direito fundamental ao meio ambiente de trabalho equilibrado. Revista Eletrônica Direito e Política, Programa de Pós-Graduação Stricto Sensu em Ciência Jurídica da UNIVALI, Itajaí, v.16, n.2, $2^{\circ}$ quadrimestre de 2021. Disponível em: www.univali.br/direitoepolitica - ISSN 1980-7791.

SERAU JÚNIOR, Marco Aurélio. Comentários à lei de benefícios da previdência social: Lei 8.213/91, de 24 de julho de 1991. Curitiba: Juruá, 2020.

SILVA, José Afonso da. Curso de direito constitucional positivo. 24. ed. São Paulo: Revista dos Tribunais, 2005.

SILVA, José Afonso da. Direito ambiental constitucional. 5. ed. São Paulo: Malheiros, 2004.

TIGRE, Maria Antonia. Implementing Constitutional Environmental Rights in the Amazon Rainforest. In: DALY, Erin; MAY, James R. (Edit.). Implementing Environmental Constitutionalism: current global challenges. 1. ed. New York: Cambridge University Press, 2018.

RECEBIDO EM: MAR/2021

APROVADO EM: JUN/2021 